\title{
Atmospheric Brown Clouds in the Himalayas: first two years of continuous observations at the Nepal Climate Observatory-Pyramid (5079 m)
}

\author{
P. Bonasoni ${ }^{1,10}$, P. Laj ${ }^{2}$, A. Marinoni ${ }^{1}$, M. Sprenger ${ }^{3}$, F. Angelini ${ }^{4}$, J. Arduini ${ }^{5}$, U. Bonafè ${ }^{1}$, F. Calzolari ${ }^{1}$, T. Colombo ${ }^{6}$, \\ S. Decesari ${ }^{1}$, C. Di Biagio ${ }^{7}$, A. G. di Sarra ${ }^{7}$, F. Evangelisti ${ }^{1}$, R. Duchi ${ }^{1}$, MC. Facchini ${ }^{1}$, S. Fuzzi ${ }^{1}$, G. P. Gobbi ${ }^{4}$, \\ M. Maione ${ }^{5}$, A. Panday ${ }^{8}$, F. Roccato ${ }^{1}$, K. Sellegri ${ }^{9}$, H. Venzac $^{2}$, GP. Verza ${ }^{10}$, P. Villani ${ }^{2}$, E. Vuillermoz ${ }^{10}$, and \\ P. Cristofanelli ${ }^{1}$ \\ ${ }^{1}$ CNR-ISAC-Institute of Atmospheric Sciences and Climate, Bologna, Italy \\ ${ }^{2}$ Laboratoire de Glaciologie et Géophysique de l'Environnement, Université Grenoble 1-CNRS, Grenoble, France \\ ${ }^{3}$ ETHZ-Swiss Federal Institute of Technology, Zurich, Switzerland \\ ${ }^{4}$ CNR-ISAC-Institute of Atmospheric Sciences and Climate, Roma, Italy \\ ${ }^{5}$ Urbino University, Chemistry Institute, Urbino, Italy \\ ${ }^{6}$ CNMCA-Climate Department, Pratica di Mare, Roma, Italy \\ ${ }^{7}$ ENEA, ACS-CLIM-OSS, Roma, Italy \\ ${ }^{8}$ Department of Environmental Sciences, University of Virginia, Charlottesville, VA, USA \\ ${ }^{9}$ Laboratoire de Météorologie Physique, CNRS-Université Blaise Pascal, Aubière, France \\ ${ }^{10} \mathrm{Ev}-\mathrm{K} 2-\mathrm{CNR}$ Committee, Bergamo, Italy
}

Received: 25 January 2010 - Published in Atmos. Chem. Phys. Discuss.: 17 February 2010

Revised: 23 July 2010 - Accepted: 26 July 2010 - Published: 13 August 2010

\begin{abstract}
This paper provides a detailed description of the atmospheric conditions characterizing the high Himalayas, thanks to continuous observations begun in March 2006 at the Nepal Climate Observatory-Pyramid (NCO-P) located at $5079 \mathrm{~m}$ a.s.l. on the southern foothills of Mt. Everest, in the framework of ABC-UNEP and SHARE-Ev-K2-CNR projects. The work presents a characterization of meteorological conditions and air-mass circulation at NCO-P during the first two years of activity. The mean values of atmospheric pressure, temperature and wind speed recorded at the site were: $551 \mathrm{hPa},-3.0^{\circ} \mathrm{C}, 4.7 \mathrm{~m} \mathrm{~s}^{-1}$, respectively. The highest seasonal values of temperature $\left(1.7^{\circ} \mathrm{C}\right)$ and relative humidity (94\%) were registered during the monsoon season, which was also characterized by thick clouds, present in about $80 \%$ of the afternoon hours, and by a frequency of cloud-free sky of less than $10 \%$. The lowest temperature and relative humidity seasonal values were registered during winter, $-6.3{ }^{\circ} \mathrm{C}$ and $22 \%$, respectively, the season being characterised by mainly cloud-free sky conditions and rare
\end{abstract}

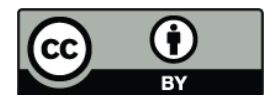

Correspondence to: P. Bonasoni (p.bonasoni@isac.cnr.it) thick clouds. The summer monsoon influenced rain precipitation (seasonal mean: $237 \mathrm{~mm}$ ), while wind was dominated by flows from the bottom of the valley (S-SW) and upper mountain (N-NE).

The atmospheric composition at NCO-P has been studied thanks to measurements of black carbon (BC), aerosol scattering coefficient, $\mathrm{PM}_{1}$, coarse particles and ozone. The annual behaviour of the measured parameters shows the highest seasonal values during the premonsoon (BC: $316.9 \mathrm{ng} \mathrm{m}^{-3}, \mathrm{PM}_{1}: 3.9 \mu \mathrm{g} \mathrm{m}^{-3}$, scattering coefficient: $11.9 \mathrm{Mm}^{-1}$, coarse particles: $0.37 \mathrm{~cm}^{-3}$ and $\mathrm{O}_{3}: 60.9$ ppbv), while the lowest concentrations occurred during the monsoon (BC: $49.6 \mathrm{ng} \mathrm{m}^{-3}, \mathrm{PM}_{1}: 0.6 \mu \mathrm{g} \mathrm{m}^{-3}$, scattering coefficient: $2.2 \mathrm{Mm}^{-1}$, and $\mathrm{O}_{3}: 38.9 \mathrm{ppbv}$ ) and, for coarse particles, during the post-monsoon $\left(0.07 \mathrm{~cm}^{-3}\right)$. At NCO-P, the synoptic-scale circulation regimes present three principal contributions: Westerly, South-Westerly and Regional, as shown by the analysis of in-situ meteorological parameters and 5-day LAGRANTO back-trajectories.

The influence of the brown cloud $(\mathrm{AOD}>0.4)$ extending over Indo-Gangetic Plains up to the Himalayan foothills has been evaluated by analysing the in-situ concentrations

Published by Copernicus Publications on behalf of the European Geosciences Union. 
of the $\mathrm{ABC}$ constituents. This analysis revealed that brown cloud hot spots mainly influence the South Himalayas during the pre-monsoon, in the presence of very high levels of atmospheric compounds (BC: $1974.1 \mathrm{ng} \mathrm{m}^{-3}, \mathrm{PM}_{1}$ : $23.5 \mu \mathrm{g} \mathrm{m}^{-3}$, scattering coefficient: $57.7 \mathrm{Mm}^{-1}$, coarse particles: $0.64 \mathrm{~cm}^{-3}, \mathrm{O}_{3}: 69.2 \mathrm{ppbv}$, respectively). During this season $20 \%$ of the days were characterised by a strong brown cloud influence during the afternoon, leading to a 5 -fold increased in the $\mathrm{BC}$ and $\mathrm{PM}_{1}$ values, in comparison with seasonal means. Our investigations provide clear evidence that, especially during the pre-monsoon, the southern side of the high Himalayan valleys represent a "direct channel" able to transport brown cloud pollutants up to $5000 \mathrm{~m}$ a.s.l., where the pristine atmospheric composition can be strongly influenced.

\section{Introduction}

During recent years, field experiments, in-situ observations and satellite monitoring have pointed to the existence of socalled atmospheric brown clouds, i.e. wide polluted tropospheric layers characterised by anthropogenic aerosol optical depth (AOD) greater than 0.3 and absorbing AOD greater than 0.03 (Ramanathan et al., 2007, and references therein). Due to the large amount of gases and aerosol particles, including black carbon, these brown clouds have strong impacts on the air quality, visibility and energy budget of the troposphere. In the past decade, scientific research has been conducted over the Indo-Asia-Pacific region, where an extensive observation system has been developed within the INDOEX project (Ramanathan and Crutzen, 2003). Such observations have served to better investigate the brown cloud extending from the Indian Ocean to the Himalayan range, attaining a vertical thickness of about $3 \mathrm{~km}$ (Ramanathan et al., 2007) during the dry season (especially from November to March), and affecting some of the most populous Asian regions, currently home to a population of more than 2 billion. For the purpose of improving knowledge about the brown cloud phenomenon and its influence on regional and global climate, air quality, public health and food security, the United Nations Environment Programme (UNEP) established the "Atmospheric Brown Cloud" $(\mathrm{ABC})$ project (www.abc-asa.uscd.edu). Although the $\mathrm{ABC}$ project activities have already allowed an improved understanding of the role of the brown cloud in affecting air-quality and climate on both the regional and global scales, a gap in knowledge still exists concerning the characterization of this cloud and its effects over the high Himalayas. In fact, even if the monitoring of atmospheric composition at high altitudes is recognised as playing an important role in climate change studies, to date only sparse experimental work has been performed in this high-altitude region (Ramanthan et al., 2008; Shresta et al., 2000; Hindman et al., 2002; Carrico et al., 2003). It should be borne in mind that, while high mountain areas are generally considered to be "clean" regions, they can be strongly impacted by anthropogenic pollution (e.g. Henne et al., 2004; Cristofanelli et al., 2009). The current study aims to foster a better understanding of the characteristics of atmospheric conditions in the Himalayas, the world highest mountain region, which is located between China and India, two of the most rapidly developing nations in the world, and primary sources of anthropogenic pollution. Some previous investigations have already suggested that the southern Himalayas are affected by significant amounts of pollution uplifted by the typical valley circulations, or advected by regional and long-range transport events (e.g. Hindman et al., 2002; Hedge et al., 2007; Bonasoni et al., 2008).

In order to study the physical, chemical and optical properties of aerosol (i.e. mass and number size distribution, $\mathrm{BC}, \mathrm{PM}_{1}$ and $\mathrm{PM}_{10}$, absorption and scattering coefficients, organic and inorganic, soluble and insoluble chemistry) as well as the surface ozone behaviour, the Nepal Climate Observatory-Pyramid (NCO-P) was installed in the high Khumbu valley (Nepal) at $5079 \mathrm{~m}$ a.s.l., in 2006 in the framework of ABC UNEP and SHARE (Station at High Altitude for Environmental research) Ev-K2-CNR projects (Bonasoni et al., 2008). Climate-altering halocarbon concentrations are also measured weekly at NCO-P, while aerosol sunphotometry studies are carried out as part of the AERONET (AErosol RObotic NETwork) program (Gobbi et al., 2010).

The objective of this paper is to investigate and evaluate the influence of the brown cloud over the Indo Gangetic Plains (IGP) on the NCO-P atmosphere composition. To this end the observational activities undertaken at NCO-P since March 2006 are presented and discussed. Instrumentation, technical set-up and analysis methodologies are initially illustrated. The meteorological conditions at the station during the first two years of activity (March 2006-February 2008) are presented, identifying the seasonal transitions as a function of local weather regime, and discussing the local and large-scale air-mass circulation that characterised the measurement site. Moreover, the seasonal behaviours of atmospheric composition at NCO-P have been analysed by describing the first 2 years of continuous observations of $\mathrm{BC}$, $\mathrm{PM}_{1}$, scattering coefficients, coarse aerosol and $\mathrm{O}_{3}$. Finally, we provide the first evaluation of the possible influence of brown cloud at high altitudes over South Himalayas.

\section{Measurements and methodologies}

\subsection{Measurement site}

The Nepal Climate Observatory-Pyramid (NCO-P, $27.95 \mathrm{~N}$, $86.82 \mathrm{E}$ ) is located at $5079 \mathrm{~m}$ a.s.l. in Sagarmatha National Park, in the eastern Nepal Himalaya, near the base camp area of Mt. Everest (Fig. 1a,b). NCO-P is sited at the confluence of the secondary Lobuche valley (oriented NNW-SSE) and 


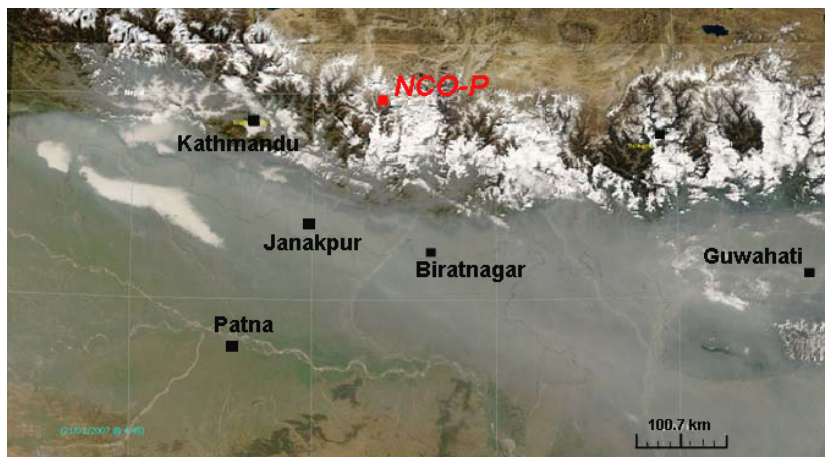

Fig. 1a. The Atmospheric Brown Cloud on the southern slope of Himalayas (MODIS sensor on NASA Terra satellite, 21 January 2007) and location of NCO-P (Nepal Climate Observatory-Pyramid, red point). The main cities in the area are also reported.

the main Khumbu valley (oriented NE-SW), a tributary of the Dudh Koshi valley, a major Ganges tributary. Forests exist only in areas of the valley below $4 \mathrm{~km}$ a.s.l., while the landscape around the measurement site is mostly rocky with patches of musk. The area is subject to short-lived snow cover periods, especially during the cold months and summer monsoon. NCO-P is located away from important anthropogenic sources of pollutants, and only small villages are present along the valley: Lobuche, Pheriche, Tyangboche, Namche Bazar (the biggest village of about 800 inhabitants), Phakding and Lukla (Fig. 1b). The closest major urban area is Kathmandu (1 081845 inhabitants; 2001 census), situated in the valley of the same name (estimated population of the valley in $2009 \sim 3$ million). The city, located about $200 \mathrm{~km}$ South-West of the measurement site and more than $3.5 \mathrm{~km}$ lower down, is characterised by high atmospheric pollution and poor air quality (Shrestha and Malla, 1996; Pudasainee et al., 2006; Panday and Prinn, 2009). The Observatory stands at the top of a hill, $200 \mathrm{~m}$ from the Pyramid International Laboratory, a multi-disciplinary high altitude research centre founded by the Ev-K2-CNR Committee and the Nepal Academy of Science and Technology in 1990 (Baudo et al., 2007). NCO-P was set up during January and February 2006, and the observation program was launched at the end of February 2006 (Bonasoni et al., 2008). The power required to carry out activities is supplied by 96 photovoltaic panels with 120 electric storage cells, in order to minimize the possible influence of local emissions and guarantee air mass sampling in clean conditions. In cases when the energy obtained from the panels is insufficient (which occurred for 6\% of hours during the summer monsoon), additional power is supplied by the photovoltaic panels at the main Pyramid facility where, only in the event of further problems, a dieselelectric generator is available. The only major event of insufficient power occurred on 14-25 June 2007, when two instruments were switched off to save energy for the other instruments. A dedicated satellite connection permits near-

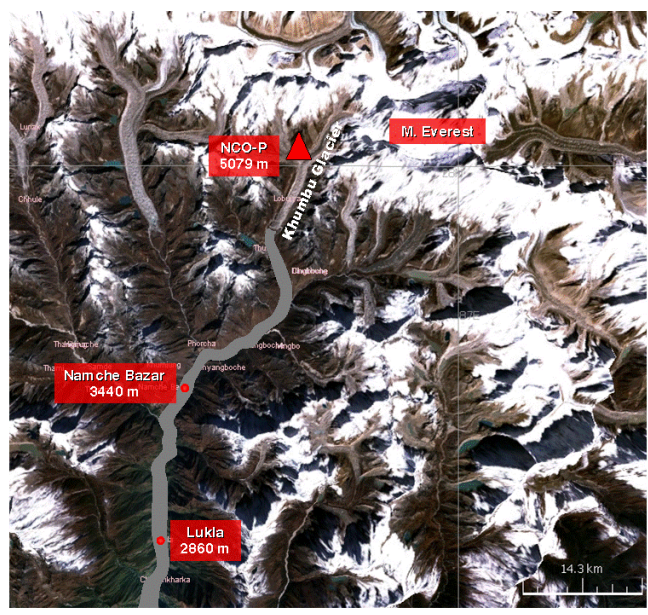

Fig. 1b. The Nepalese Khumbu valley (thick grey line) and NCO-P (red triangle). Modified by NASA World Wind, http://worldwind. arc.nasa.gov/.

real-time data transfer, as well as the remote control of instrumentation. Further details on the measurement site can be found in Bonasoni et al. (2007) and Bonasoni et al. (2008).

\subsection{Measurements and sampling procedures}

Starting in March 2006, a wide range of measurements for aerosols and trace gases characterisation have been continuously running at NCO-P. In particular, the following instruments are housed in a wood and aluminium shelter:

1. Photometric $\mathrm{O}_{3}$ analyser (Thermo Electron Corporation-Tei 49C) operating at the wavelength of $254 \mathrm{~nm}$. Data are first stored on a 1-minute basis and finally validated as 30 -minute average values. The sampling methodology was based on the GAW-WMO requirements (GAW, 1992). For more details on the experimental set-up see Cristofanelli et al. (2010)

2. Multi-Angle Absorption Photometer (MAAP 5012, Thermo Electron Corporation) operating at the wavelength of $670 \mathrm{~nm}$, measuring aerosol light absorption. The MAAP calculates absorbance from particles deposited on the filter using measurements of both transmittance and reflectance at three different angles. For more details on the experimental set-up see Marinoni et al. (2010).

3. Differential/Scanning Mobility Particle Sizer (DMPS/SMPS) determining the aerosol size distribution for particle diameters from 10 to $500 \mathrm{~nm}$ and the Total Particle Count, with a three-minute time resolution. For more details on the experimental set-up see Sellegri et al. (2010). 
4. Aerosol total and back scattering coefficients at three wavelengths $(450,550$ and $700 \mathrm{~nm})$ are derived by an integrating nephelometer (model TSI 3563). Over the course of the 2-year period, a number of problems limited the measurements: from 1 November 2006 to 10 February 2007, and from 10 December 2007 to 25 February 2008. For more details on the experimental set-up see Marcq et al. (2010).

5. Optical Particle Counter (OPC, GRIMM 190) determining the aerosol size distribution for particle diameters from 0.25 up to $32 \mu \mathrm{m}$ in 31 channels, with an accuracy of $2 \%$, on concentrations. Coarse particles, with diameters larger than $1 \mu \mathrm{m}$ are considered as a proxy of dust aerosol. From the OPC measurements the mass concentrations of $\mathrm{PM}_{1}$ were derived. Due to instrument failure, the measurements were interrupted on $4 \mathrm{De}$ cember 2007 and resumed on 5 February 2008. For more details on the experimental set-up and number and mass calibrations, see Marinoni et al. (2010), Duchi et al. (2010).

6. Cimel CE-318 sunphotometer installed at NCO-P at the end of March 2006 within the framework of the Aerosol Robotic Network, AERONET (http://aeronet.gsfc.nasa. gov, EvK2-CNR site). It provides a characterization of aerosol optical and microphysical properties of the air column above the station. For more details on the experimental set-up see Gobbi et al. (2010).

7. Kipp\&Zonen CMP21 pyranometer, measuring downward solar irradiance throughout the $305-2800 \mathrm{~nm}$ spectral range. The CMP21 was installed in March 2007. Measurements were interrupted due to technical problems in November 2007 and resumed in February 2008. The solar irradiance and instrument body temperatures are acquired every $60 \mathrm{~s}$. The CMP21 has a very good cosine responsivity (cosine error less than $0.4 \%$ for solar zenith angles smaller than $80^{\circ}$ ). The temperature dependence is also small (less than $0.5 \%$ within the range $-20 \div+50^{\circ} \mathrm{C}$ ), and the spectral responsivity is uniform within the measurement range $(95 \%$ points at $335-2200 \mathrm{~nm}$ ). The CMP21 was calibrated at Kipp\&Zonen in November 2007, based on the World Radiometric Reference of the WMO. The estimated total uncertainty on hourly irradiance values is less than $2 \%$.

8. High volume aerosol sampler $\left(30 \mathrm{~m}^{3} \mathrm{~h}^{-1}\right)$ and low-volume sampler $\left(1 \mathrm{~m}^{3} \mathrm{~h}^{-1}\right)$ collecting, noncontinuously, particulate matter on quartz fibre filters for off-line chemical analyses. For more details on the experimental set-up and sampling strategy refer to Decesari et al. (2010).

9. VAISALA Weather Transmitter WXT510 measuring wind speed and direction, atmospheric pressure, air temperature and relative humidity. Precipitation is also measured with a piezoeletrical sensor: this type of sensor can underestimate total precipitation due to the omission of snowfalls.

The sampling of ambient air is performed using four different inlets installed on the shelter roof at about $4 \mathrm{~m}$ a.g.l.:

- $\mathrm{PM}_{2.5}$ head for nephelometer and DMPS/SMPS instruments (flow rate: $1 \mathrm{~m}^{3} \mathrm{~h}^{-1}$ ).

- Total Suspended Particle (TSP) head for the optical particle counter $\left(0.018 \mathrm{~m}^{3} \mathrm{~h}^{-1}\right)$

- $\mathrm{PM}_{10}$ head for non-continuous high volume aerosol sampling $\left(30 \mathrm{~m}^{3} \mathrm{~h}^{-1}\right)$

- second TSP head for $\mathrm{O}_{3}$ and $\mathrm{BC}$ measurements $\left(15 \mathrm{~m}^{3} \mathrm{~h}^{-1}\right)$

- $\mathrm{PM}_{1}$ head for non-continuous low volume aerosol sampling $\left(1 \mathrm{~m}^{3} \mathrm{~h}^{-1}\right)$.

All the atmospheric compound concentrations measured at NCO-P and reported herein refer to STP conditions, while hours of the day refer to Nepal Standard Time, (NST), corresponding to UTC+5.45.

\section{Meteorological characterization and air mass circulation}

\subsection{Seasonal weather regime behaviour}

The Himalayan high-altitude climate is intensely characterised by its relationship with large-scale circulation, and strongly dominated by the diurnal cycle of thermal parameters (Bollasina et al., 2002). In fact, at NCO-P, the seasonal variation of atmospheric conditions is influenced both by the local mountain wind system (with a strong diurnal valley wind and a weak mountain night-breeze), and by the large-scale Asian monsoon circulation. In particular, besides determining the seasonal variations of meteorological parameters, the annual variations of the main synoptic circulation can also modulate the diurnal cycles characterizing the local mountain weather regime (Barros and Lang, 2003; Ueno et al., 2008).

Time series of atmospheric pressure $(\mathrm{P})$, air temperature $(\mathrm{T})$, relative humidity $(\mathrm{RH})$, rain precipitation (PRP), wind speed (WS) and direction (WD) are shown in Fig. 2 for the period from March 2006 to February 2008. As shown in Fig. 2a, P behaviour is characterized by higher (and less variable) values from June to August (average value: $552.4 \pm 1.4 \mathrm{hPa}, \pm 1$ sigma) and lower (and more variable) values from November to March (average value: $546.8 \pm 3.9 \mathrm{hPa}$ ) with an average value of $550.9 \pm 3.6 \mathrm{hPa}$ Such behaviour reflects the development of the "Tibetan 


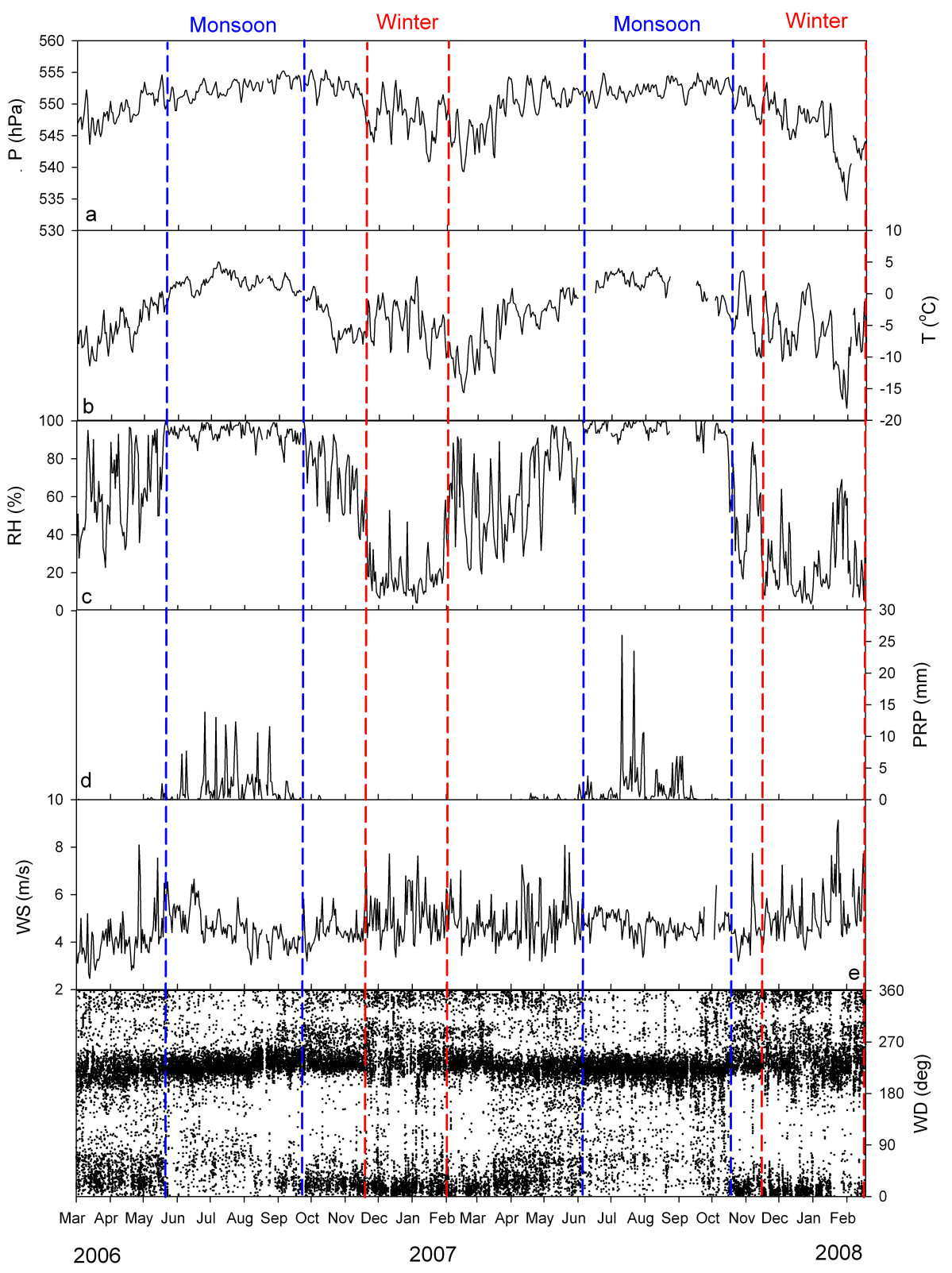

Fig. 2. Behaviour of atmospheric pressure (a), temperature (b), relative humidity (c), rain precipitation (d), wind speed (e) and wind direction (f) at NCO-P from 1 March 2006 to 28 February 2008. Monsoon (blue) and winter (red) season onset and offset dates are represented by vertical lines.

High" during summer in the upper troposphere and the oscillations of the Subtropical Jet Stream (SJS), as well as the passage of eastward propagating synoptic disturbances during the rest of the year (Bohmer, 2006; Schiemann et al., 2009). The daily behaviour of $\mathrm{P}$ shows a systematic semidiurnal variation characterised by an amplitude of about $1-2 \mathrm{hPa}$, with diurnal maxima at 10:00-22:00 NST and diurnal minima at 04:00-16:00 NST. This semidiurnal pressure cycle, with highest amplitude during January-February $(\sim 2.2 \mathrm{hPa})$ and lowest during June-August $(\sim 1.0 \mathrm{hPa})$, had already been observed in Himalayas (Ueno and Pokherel, 2002) and at other high altitude sites (e.g. Petenko and Argentini, 2002). It was explained in terms of the atmospheric tidal theory, relating to the warming of upper atmospheric layers due to the interaction between $\mathrm{O}_{3}$ molecules and solar radiation (Chapman and Lindzen, 1970).

During the considered period, $\mathrm{T}$ showed a mean value of $-3.0 \pm 4.5^{\circ} \mathrm{C}$ and exhibited a seasonal behaviour (Fig. 2b) characterised by a maximum during the summer period (average value: $1.7 \pm 2.1^{\circ} \mathrm{C}$ ), the highest values being measured in July (even above $8^{\circ} \mathrm{C}$ ). Lower $\mathrm{T}$ values were recorded during winter (average value: $-6.3 \pm 4.5^{\circ} \mathrm{C}$ ), the lowest 
being observed in January-February (below $-15^{\circ} \mathrm{C}$ ). Such behaviour agrees well with the analysis of the SJS location and $500 \mathrm{hPa}$ geopotential height carried out in the light of the European Centre for Medium Range Weather Forecasts (ECMWF) analysis (here not shown). In fact, since the SJS determines the northern limit of warmer subtropical air, it is realistic to expect an increase in air temperature when the SJS moves northward of the Himalayas (from May to September). By contrast, from October to February, the SJS is located at lower latitudes and the Himalayan range can be affected by cold air mass irruptions. This was the case in January 2007 , when the lowest $\mathrm{T}$ daily value $\left(-18^{\circ} \mathrm{C}\right)$ was recorded at NCO-P. However, as suggested by the high standard deviation, during the cold months, $\mathrm{T}$ showed a large variability, with daily values even above $-1{ }^{\circ} \mathrm{C}$. Such "warm events" were already highlighted by Bollasina et al. (2002), and have been related to the passage of synoptic disturbances affecting the high Khumbu valley region, transporting warmer, moister air masses from the Arabian Sea (Ueno and Pokhrel, 2002). This could be the case also of NCO-P, since "warm events" are also characterised by significant simultaneous variations of $\mathrm{P}$ and $\mathrm{RH}$ average daily values (Fig. 2a and c).

The RH behaviour at NCO-P (Fig. 2c) was characterized by a clear seasonal cycle, with very low values from the end of November to January/February (average value: $22 \pm 14 \%$ ) and high values from the end of May to the end of September (average value: $94 \pm 4 \%$ ). Since RH behaviour in the Southern Himalayas is strongly influenced by the South Asian monsoon cycle due to the transport of moist air masses from the Indian Ocean (e.g., Krishnamurti and Bhalme, 1976; Barros and Lang, 2003), this parameter was used to evaluate the monsoon phase over the considered region.

The analysis of the PRP time-series (Fig. 2f) also highlighted the seasonal influence of the summer monsoon at NCO-P. At the measurement site, monsoon precipitations ( $237 \mathrm{~mm}$ in 2006 and $238 \mathrm{~mm}$ in 2007) were characterised by light showers or drizzles, more frequent in the evening and at night, while only sporadic events with heavier rain ( $>10 \mathrm{~mm} /$ day) were detected (Fig. 2d). However, it should be noted that such values could be underestimated due to the loss of snowfall (see Sect. 2). This would also explain the absence of any signal of precipitation from November to April, when $92 \%$ of 30-minute observations showed airtemperatures below $0^{\circ} \mathrm{C}$.

During the investigated period, daily values of WS were characterised by an average value of $4.7 \pm 1.0 \mathrm{~m} \mathrm{~s}^{-1}$ (Fig. 2e). Thus, despite its elevation, the measurement site does not appear to be an extremely windy location, thanks to the sheltering effect of the mountain ridge. Wind speed above $6 \mathrm{~m} \mathrm{~s}^{-1}$ was mainly observed from November to May, and was probably due to the passage of synoptic disturbances (see, for instance, the simultaneous P decrease on 22 November 2006 or on 24 January 2008). On average, these months appeared slightly more "gusty" (standard deviation: $1.1 \mathrm{~m} \mathrm{~s}^{-1}$ ) com-
Table 1. Identification of seasonal transitions as a function of the local weather regime.

\begin{tabular}{lll}
\hline Year & Season & Start day-End day \\
\hline \multirow{2}{*}{2006} & Pre-monsoon & 1 March-20 May \\
& Monsoon & 21 May-26 September \\
& Post-monsoon & 27 September-20 November \\
\hline \multirow{2}{*}{2007} & Winter & 21 November 2006-31 January 2007 \\
& Pre-monsoon & 1 February-5 June \\
& Monsoon & 6 June-12 October \\
& Post-monsoon & 13 October-14 November \\
\hline \multirow{2}{*}{2008} & Winter & 15 November-18 February 2008 \\
\hline
\end{tabular}

pared to summer months (standard deviation: $0.6 \mathrm{~m} \mathrm{~s}^{-1}$ ), probably as a result of the more effective occurrence of the SJS over the Southern Himalayas.

At NCO-P, WD showed a bidirectional distribution, with dominating directions from the bottom of the valley (S-SW) and from the upper mountain (N-NE). This was related to the development of a strong mountain-valley breeze regime (Bollasina et al., 2002), brought about by the thermal heating of valley and mountain slopes (e.g. Henne at al., 2005). For most of the year (October to May), valley winds prevailed during day-time, while mountain winds prevailed during night-time (Fig. 2d). During the summer months, due to the large scale forcing of the South Asian monsoon (Ueno et al., 2008), valley breeze winds are predominant also during night-time. This was reflected by the seasonal frequency of valley winds, which was characterised by an $80 \%$ occurrence from June to September and a $45 \%$ one from November to April. Due to this abrupt change in local circulation, WD was also used to define the monsoon phase over the considered region.

\subsection{Identification of season transitions}

In the present work, sudden variations in the mountain weather regime (as defined by $\mathrm{RH}$ and WD behaviour) were used to identify the onsets and decay dates of the summer monsoon and winter seasons. The winter season was identified when daily RH values never exceeded $70 \%$, and northerly mountain winds were well established during night-time. In agreement with Ueno et al. (2008), the monsoon season was defined as the period characterised by high humidity levels, and the presence at the measurement site of southerly winds, also during night-time. In fact, from May to September, an evident decrease in the frequency of mountain winds was observed, and southerly winds could prevail even during night-time. As suggested by Barros and Lang (2003) and Ueno et al. (2008), this change in local circulation could represent in-situ evidence for the onset of the large scale summer monsoon flow from the Indian plains to 


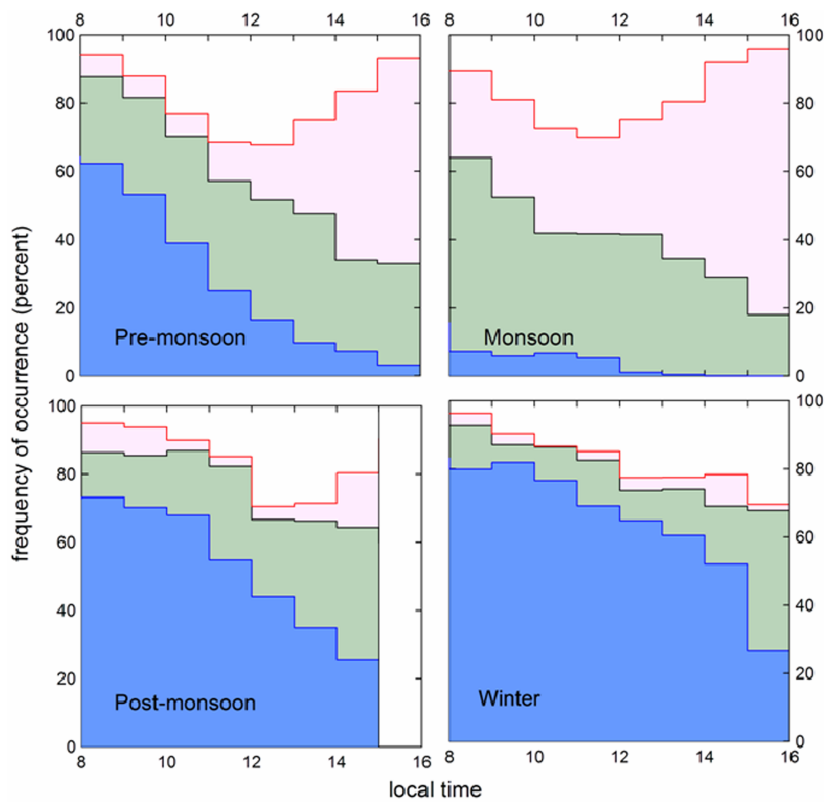

Fig. 3. Frequency of occurrence of clear skies (light blue), thin/moderate clouds (grey), thick clouds (pink), and scattered clouds (white) versus time of day for the different seasons, as derived from the CMP21 observations.

the Tibetan Plateau. In good agreement with the analyses of Rajeevan and Revadekar $(2007,2008)$, the combined analysis of RH and wind regime changes led to the seasonal definition reported in Table 1. It should be noted that the onset dates of the monsoon season, thus defined (21 May 2006 and 6 June 2007), are ahead of the onset of the rainy season at NCO-P by about two weeks. In fact, Bollasina et al. (2002) identified 12 June as the average onset date for summer monsoon precipitation, analysing six-years (19941999) of daily precipitation data at this site. Our results are in good agreement with those of Ueno et al. (2008) and Barros and Lang (2003), showing that in the Southern Himalayas significant changes in mountain weather regime, due to the summer onset of the large scale southern monsoon circulation, strongly anticipate the precipitation onset.

\subsection{Sky conditions and cloud classification}

To identify cloud-free and cloudy periods at NCO-P from pyranometer measurements, a simple algorithm was implemented. First, a cloud-free day characterized by low aerosol and pristine conditions was identified. Following Long and Ackermann (2000), the measured irradiance was fitted with the expression

$I(\theta)=A[\cos (\theta)]^{\alpha}$

where $\theta$ is the solar zenith angle, and $A$ and $\alpha$ are constants. The standard deviation $\sigma$ of the ratio $R$ between the observations and the fitting curve at the corresponding solar zenith angles was calculated over 10-min intervals. The observations whose values of $\sigma$ exceeded a fixed threshold (0.005) were labelled as cloudy. In addition, because the irradiance variability was small in a few cases of overcast sky with thick cloud, cases with measured irradiances outside a $20 \%$ range of the clear-sky fitting curve were also labelled as cloudy. Only cases with solar zenith angle smaller than $70^{\circ}$ were considered, since shadowing of the sensor by mountains sometimes occurred during the year for larger values of $\theta$. The method is efficient in identifying clouds, and results agree well with determinations of cloudy periods based on visual inspection of the daily course of measured irradiances by an experienced operator. Cloudy periods were further separated into classes, qualitatively identified as thin/moderate, thick, or scattered, depending on the value of $R$. Thick clouds are those corresponding to $R \leq 0.5$. According to the algorithm of Barnard and Long (2004), $R=0.5$ roughly corresponds to a cloud optical depth of 8 over a surface not covered by snow or ice. Figure 3 shows the frequency of occurrence of the different conditions during the day, summed over the main seasons identified above. Due to the limit on the value of $\theta$, information after 15:00 NST for the post-monsoon season is not available. The sky conditions clearly show different behaviours during the four seasons, in response to large scale dynamical phenomena. The average daily evolution in the different seasons sometimes shows a strong diurnal cycle, partly determined by local circulation. Thick clouds were present in up to $50 \%$ of the cases in the afternoon during the pre-monsoon and, consistently with the precipitation data reported in Fig. 2d, their occurrence increased during the monsoon season, with a frequency of about $80 \%$ in the mid-afternoon. Thick clouds were found to be less frequent in the post-monsoon, and rare during the winter season. As expected, cloud-free skies are most common in the winter season, while their frequency is smaller than $10 \%$ during the monsoon period. A distinctive daily behaviour appears, with cloud-free conditions occurring mostly during the morning throughout the year. Thin/moderate clouds seem to display a smaller daily evolution, particularly in the pre-monsoon season. The diurnal cycle is large in the non-monsoon seasons, while it is reduced during the monsoon, as an effect of the interaction between large scale and local circulation, and the influence of cloudy conditions (present in more than $90 \%$ of cases throughout the day) on valley wind development.

\subsection{Local circulation description}

At NCO-P the wind regime was characterised by an evident mountain/valley breeze circulation, as shown by the analysis of the southern wind component $(\mathrm{Vy})$ from postmonsoon to pre-monsoon (Fig. 4, upper plate), while in the monsoon season southerly winds were predominant. During the pre-monsoon, valley winds $(\mathrm{Vy}>0)$ were evident from about 09:00 to 20:00 NST, and from 09:00 to 18:00 NST during the post-monsoon and winter season. The slightly 

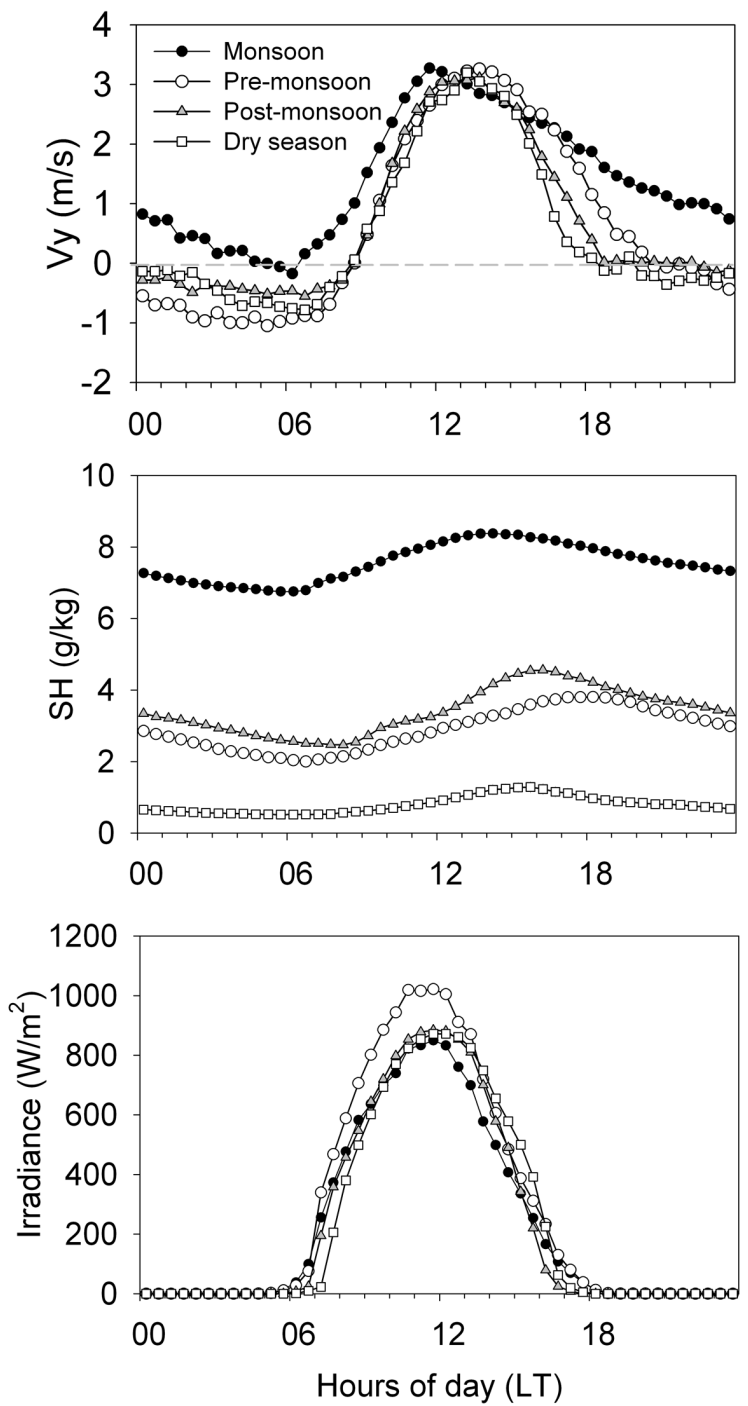

Fig. 4. Average seasonal diurnal variations of southerly wind component (Vy, upper plate), specific humidity ( $\mathrm{SH}$, middle plate) and solar irradiance (bottom plate) at NCO-P during the pre-monsoon (white circles), monsoon (black circles), post-monsoon (grey triangles) and winter (white squares) seasons.

stronger valley winds observed in the afternoon during the pre-monsoon can be explained by the stronger driving force caused by the more efficient ground heating (Bollasina et al., 2002). During night-time, the wind flow reversed $(\mathrm{Vy}<0)$ but showed lower intensity compared to the day-time valley winds. This mountain wind system clearly influenced the diurnal behaviour of moisture at the measurement site. In fact, even if the diurnal variation of specific humidity ( $\mathrm{SH}$, Fig. 4, middle plate) was small when compared to seasonal variation (from about $1 \mathrm{~g} \mathrm{~kg}^{-1}$ during the Winter season to $3-4 \mathrm{~g} \mathrm{~kg}^{-1}$ during the pre-monsoon and post-monsoon), the valley breeze favoured the transport of moisture from lower altitudes during day-time, the highest $\mathrm{SH}$ values (about
3-4 $\mathrm{g} \mathrm{kg}^{-1}$ ) being recorded from 16:00 to 18:00 NST. The pre-monsoon evolution of local wind fields around NCO$\mathrm{P}$ was confirmed by WRF simulations for a selected day (i.e. 30 March 2006, see Fig. S2 in the supplementary material).

During the monsoon season, significant changes in the local wind regime were observed at NCO-P, bringing moisture from the bottom to the top of the Khumbu valley, due to the strong heating of the ground and the consequent release of large quantities of latent heat into the atmosphere. The average diurnal variation of $\mathrm{Vy}$ showed increasing values in the morning (with the valley breeze) and a maximum around midday, with decreasing values until night, when the southerly winds were still observed at the measurement site (Fig. 4). As shown by WRF simulations for a specific monsoon day (i.e. 14 July 2007, see Fig. S3 in the supplementary material), during day-time the up-valley wind observed at NCO-P was related to very pronounced flows onto the Tibetan Plateau, which originated from the lower valleys of Nepal. Also during night-time, the upper reaches of the valleys continue to show a southerly flow towards the Tibetan Plateau. This is in agreement with previous investigations by Ueno et al. (2008) and Barros and Lang (2003), suggesting that during night-time the measurements carried out at NCO-P can be representative of the large-scale monsoon flow between the Indian plains and Tibetan Plateau. During the monsoon season, the day-time valley breeze showed a gentler decreasing trend toward the evening (Fig. 4, upper plate), probably due to the "pumping effect" of the latent heat release relating to water vapour condensation on cumulous clouds (Bollasina et al., 2002). During this season, the SH diurnal variation characterized by high values (in average above $7 \mathrm{~g} \mathrm{~kg}^{-1}$ ) with maximum after midday, indicated the efficient transport of moist air masses from the bottom of the valley, with a larger presence of clouds at NCO-P. This was further confirmed by the analysis of solar irradiance (Fig. 4, bottom plate), which showed lower irradiance levels during the monsoon noon-afternoon (average value at 12:00 NST: $832 \pm 342 \mathrm{~W} \mathrm{~m}^{-2}$ ) than in other seasons (average value at 12:00 NST: $954 \pm 242 \mathrm{~W} \mathrm{~m}^{-2}$ ).

\subsection{Large scale circulation}

Located on the south-facing side of the Himalayas, the upper Khumbu valley is particularly affected by large scale circulation. In fact, signals of the so-called Tropospheric Biennial Oscillation (Webster et al., 1998) were found by Bertolani et al. (2000) analysing in-situ meteorological parameters at the Pyramid International Laboratory, while Bollasina et al. (2002) showed a clear link between intra-seasonal precipitation variation in the upper Khumbu valley and largescale circulation modes. In this area, the seasonal weather behaviour depends on variations in the "Tibetan High", a strong thermal anticyclone forming in the upper troposphere during summer season, and correlating with the strength and 


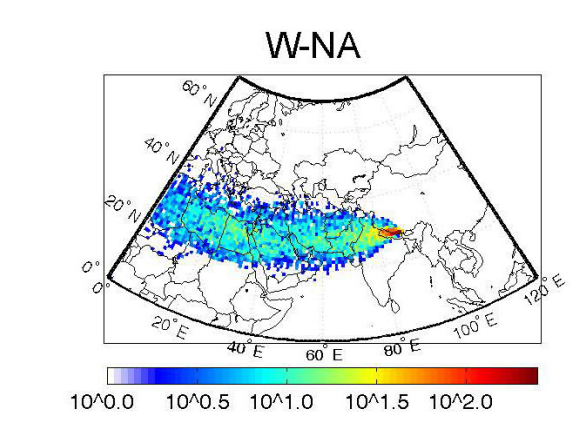

Westerly, W: $43.3 \%$
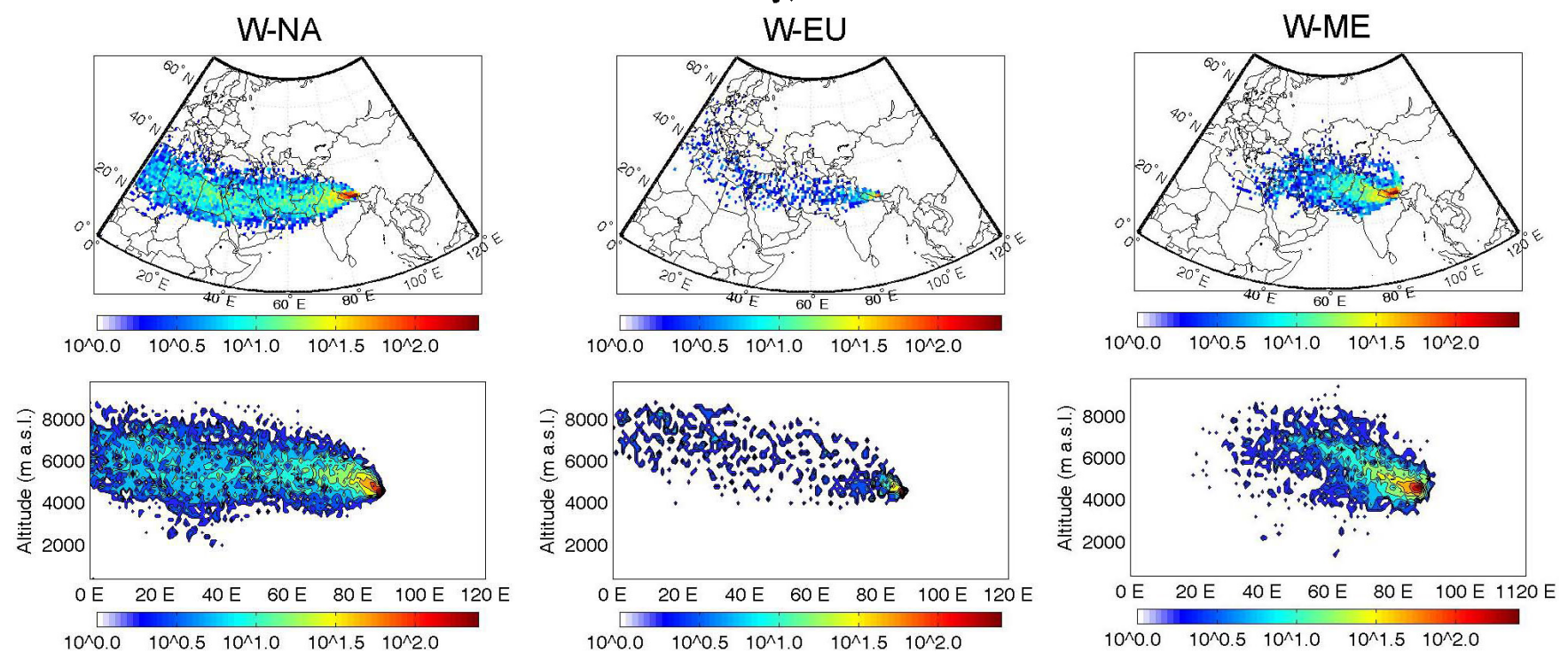

Fig. 5a. Westerly "W" clusters of night-time 3-D back-trajectories at NCO-P for the period March 2006-18 February 2008 (vertical cross section included). The frequency of cluster occurrence is reported in the Fig. 6.

location of the SJS during the rest of the year (Krishnamurti and Bhalme, 1976; Bertolani et al., 2000; Ueno et al., 2001). During the cold season, from October to May, in the upper troposphere the axis of the SJS is just south of the Himalayas, and synoptic disturbances travel eastward affecting the southern slopes of the mountain ridge (Ueno et al., 2001). Moving into summer, the SJS starts to oscillate between northern Tibet and the southern Himalayas (Barros and Lang, 2003). This leads to a weakening of general zonal flows, which can provide favourable conditions for the development of daytime convection over the southern Himalayas, thus modulating the onset of the summer monsoon rainy season (Barros and Lang, 2003; Ueno et al., 2008). In JuneAugust, the SJS is situated in northern Tibet, and the "Tibetan High" becomes the predominant synoptic pattern at upper levels. The migration of monsoon depressions from the northern Gulf of Bengal (Ueno et al., 2008) and the low-level cross-equatorial jet (Krishnamuti and Bhalme, 1976) may influence the regional weather and total column moisture over the Himalayas.

In order to determine the synoptic origin of air masses reaching NCO-P, 5-day back-trajectories were calculated every $6 \mathrm{~h}$ (at 05:45, 11:45, 17:45 and 23:45 NST) with the Lagrangian Analysis Tool LAGRANTO (Wernli and Davies, 1997). Trajectory calculations were based on the 6-hourly operational analyses produced by the ECMWF. The 3-D wind fields were interpolated onto a horizontal $1^{\circ} \times 1^{\circ}$ grid and are available on 60 hybrid vertical levels. For every point along the trajectory (time resolution: $2 \mathrm{~h}$ ), the model provides the geographic location and altitude of the air parcel, as well as other important physical quantities, like Er- tel's potential vorticity. Due to the very complex topography of the NCO-P area and the influence of local/regional transport phenomena related to thermal valley winds, backtrajectory results should be treated with caution. Therefore, in order to capture the dominant synoptic-scale circulations and minimize the interference of local valley winds, a nonhierarchical cluster analysis was applied to night-time LAGRANTO back-trajectories. Applying a version of the cluster methodology presented in Dorling et al. (1992), an apriori number of appropriate clusters was not fixed. At each step of the agglomeration process, the appropriate number of clusters was determined by analysing the variations of specific statistical parameters, i.e. total trajectory dispersion and total root mean square deviation (see Tarasova et al., 2007; Dorling et al., 1992). The clustering algorithm was applied to the middle members (see Scheele and Siegmund, 2001) of the LAGRANTO ensemble calculated for the NCO-P pressure level and composed of seven back-trajectories.

Depending on the geographical origin and paths of the analysed back-trajectories, 7 clusters were identified, divided into three main classes: "SW" south-westerly (SW-AP: Arabian Peninsula, SW-AS: Arabian Sea, SW-BG: Bengal Gulf); "W" westerly (W-NA: North Africa, W-EU: Europe, W-ME: Middle East); and "REG" regional, as shown in Fig. 5. Significant variations in the cluster frequencies among the different seasons were found, as shown by the seasonal cluster analyses at NCO-P (Fig. 6). In particular, the three "W" clusters characterised $43.3 \%$ of the investigated period (Fig. 5), suggesting the prevalent role of the SJS and westerly synoptic scale systems in influencing the atmospheric circulation over the south-eastern Himalayas (particularly during 

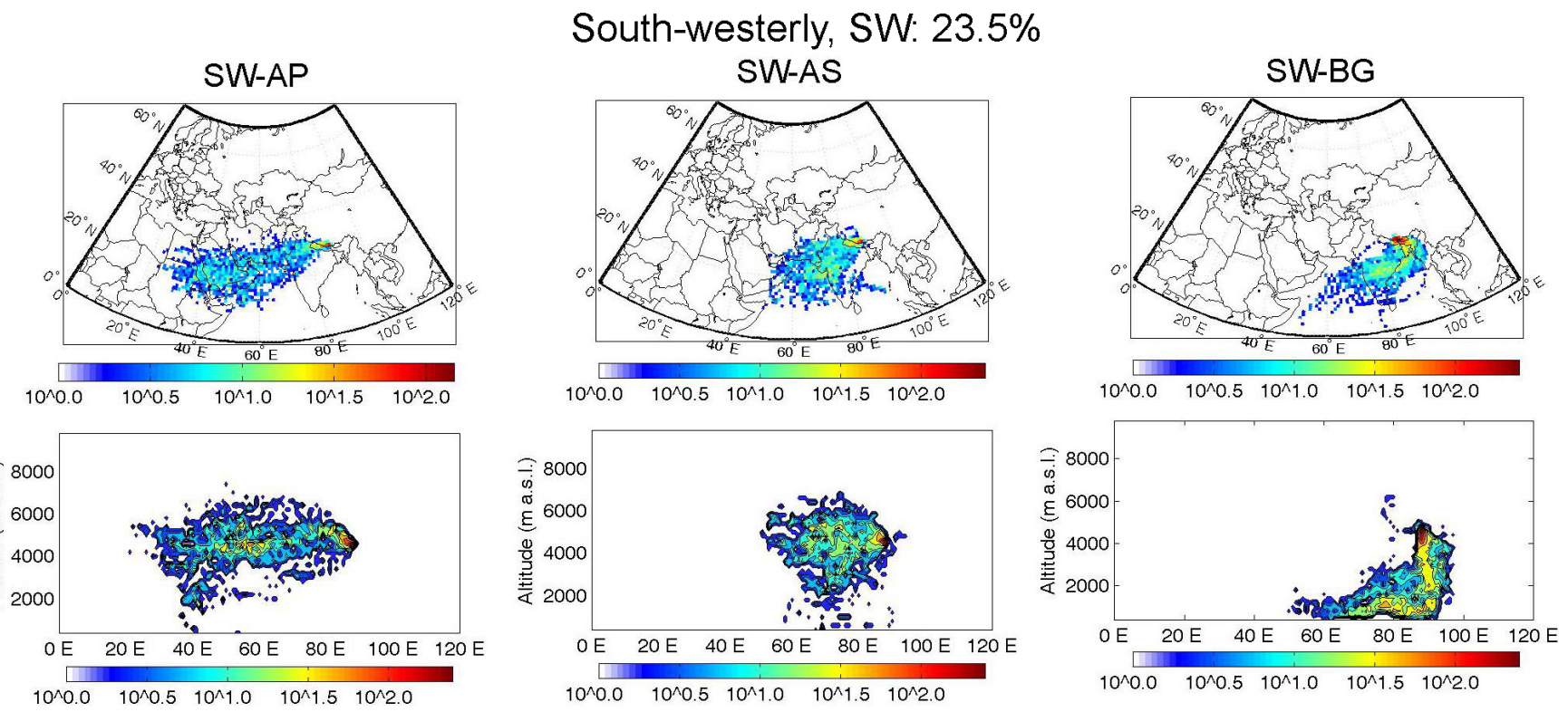

Fig. 5b. As in Fig. 5a but for south-westerly "SW" clusters.

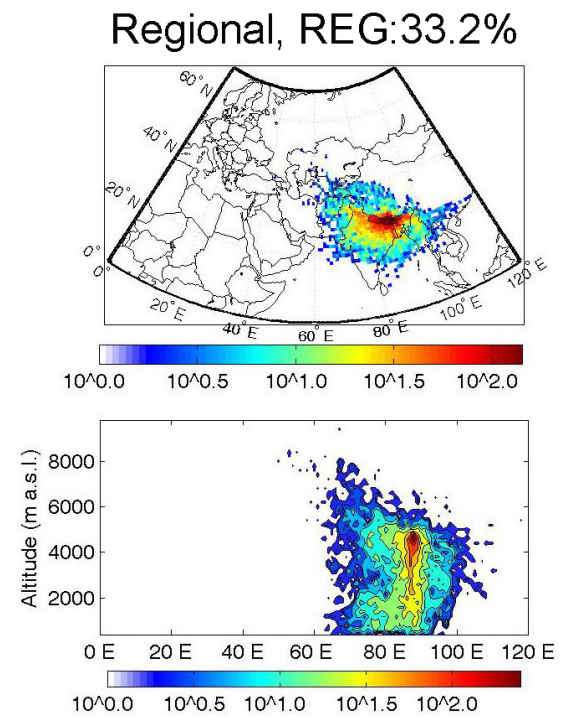

Fig. 5c. As in Fig. 5a but for regional "REG" cluster.

non-monsoon seasons). The cluster analysis also showed a not negligible contribution on the part of the "SW" circulations, which were established at NCO-P for $23.5 \%$ of the analysed period. According to Böhmer et al. (2006) and Barros and Lang (2003), these circulation classes are related to the passage of synoptic-scale disturbances over the western Indian subcontinent and Himalayas (SW-AS and SW-AP) during non-monsoon seasons, and to the development of the well-established monsoon circulation over the Gulf of Bengal (SW-BG) during the monsoon season. As also shown by the cluster vertical cross-sections (Fig. 5), "SW" circu- lations were characterised by synoptic-scale air mass uplift. The importance of the synoptic uplift of regional polluted airmasses during the 2-year period was further stressed by the high frequency of the "REG" air-mass cluster which dominated the atmospheric circulation during the monsoon season (Fig. 6). All the previous results, magnify the different atmospheric circulation characterising the high Himalayas with respect to the South Asia plains. While in the South Asia boundary layer a northerly to north-easterly circulation usually prevails, in the middle and upper troposphere the mean flow turns to westerly (Phandis et al., 2002), thus indicating a synoptic-scale decoupling of the middle troposphere circulation from the lower troposphere, particularly during nonmonsoon seasons.

\section{Atmospheric composition at NCO-P}

Long term observations at NCO-P permitted a first continuous characterization of atmospheric composition over the southern Himalayas, also permitting the investigation of possible influence of atmospheric brown cloud hot spots from IGP and Himalayas foothills. The characteristics of atmospheric composition at NCO-P is determined by the South Asia summer monsoon cycle, highlighted by the variation of the seasonal behaviours of $\mathrm{BC}$, scattering coefficient, $\mathrm{PM}_{1}$, coarse particles and $\mathrm{O}_{3}$, as shown in the Fig. 7, and by their seasonal mean values (Table 2 ). The lowest seasonal values of BC (49.6 $\left.\mathrm{ng} \mathrm{m}^{-3}\right)$, scattering coefficient $\left(2.2 \mathrm{Mm}^{-1}\right)$, $\mathrm{PM}_{1}\left(0.6 \mu \mathrm{g} \mathrm{m}^{-3}\right), \mathrm{O}_{3}$ (38.9 ppbv) characterised the monsoon, while coarse particles $\left(0.09 \mathrm{~cm}^{-3}\right)$, reached the minimum during post-monsoon (Table 2). In this season $96 \%$ 
Table 2. Seasonal average (mean \pm standard deviation) of $\mathrm{BC}$, aerosol scattering coefficient, $\mathrm{PM}_{1}$, coarse particle number and $\mathrm{O}_{3}$ at $\mathrm{NCO}-\mathrm{P}$ during the period March 2006-February 2008. Seasons are defined following Table 1. In the last column, means \pm standard deviations are reported for the Atmospheric Brown Cloud hot-spot episodes identified at NCO-P during the pre-monsoon season (see Sect. 4.1).

\begin{tabular}{llllll}
\hline & Pre-Monsoon & Monsoon & Post-Monsoon & Winter & ABC hotspots \\
\hline $\mathrm{BC}\left(\mathrm{ng} \mathrm{m}^{-3}\right)$ & $316.9 \pm 342.9$ & $49.6 \pm 60.9$ & $135.3 \pm 78.5$ & $118.4 \pm 80.9$ & $1974.1 \pm 896.1$ \\
Scattering & $11.9 \pm 10.5$ & $2.2 \pm 3.5$ & $5.0 \pm 2.9$ & $3.4 \pm 1.6$ & $57.7 \pm 28.2$ \\
coefficient $\left(\mathrm{Mm}^{-1}\right)$ & & & & \\
$\mathrm{PM}_{1}\left(\mu \mathrm{g} \mathrm{m}^{-3}\right)$ & $3.9 \pm 4.0$ & $0.6 \pm 1.0$ & $1.5 \pm 0.8$ & $1.3 \pm 1.8$ & $23.5 \pm 10.2$ \\
${\mathrm{Coarse}\left(\mathrm{cm}^{-3}\right)}^{0.37 \pm 0.37}$ & $0.09 \pm 0.02$ & $0.07 \pm 0.05$ & $0.16 \pm 0.14$ & $0.64 \pm 0.33$ \\
$\mathrm{O}_{3}(\mathrm{ppbv})$ & $60.9 \pm 8.4$ & $38.9 \pm 9.6$ & $46.3 \pm 5.0$ & $51.2 \pm 5.4$ & $69.2 \pm 10.4$ \\
\hline
\end{tabular}

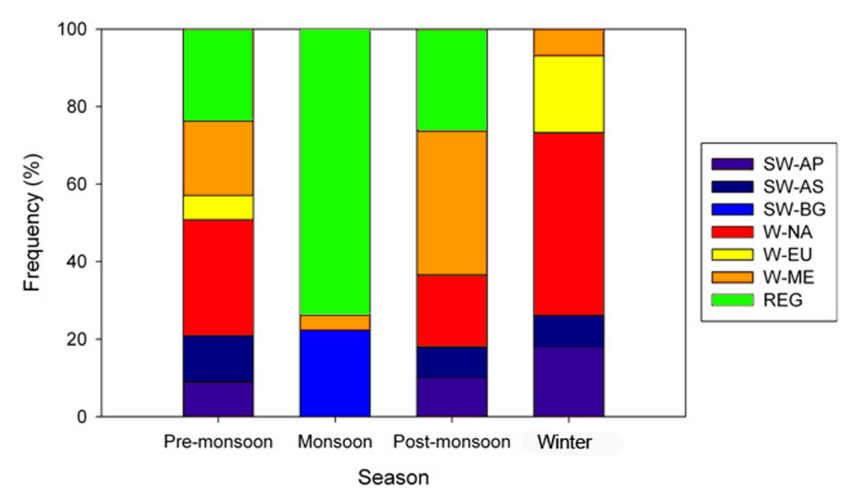

Fig. 6. Seasonal cluster frequencies at NCO-P for the period March 2006-February 2008: SW-AP (South Westerly-Arabian Peninsula), SW-AS (South Westerly-Arabian Sea), SW-BG (South Westerly-Bengal Gulf), W-NA (Westerly-North Africa), W-EU (Westerly-Europe), W-ME (Westerly-Middle East), REG (Regional).

of air-masses reaching NCO-P were related to synoptic-scale uplift and characterised by large occurrence of "REG" and "SW-BG" circulations (Figs. 5 and 6) usually associated with strongly precipitating low pressure systems over the Bay of Bengal (Barros and Lang, 2003). Conversely, when unusual but intensive westerly shifts in the monsoon circulation occurred, large amounts of pollutants (i.e. BC and $\mathrm{O}_{3}$ ) and mineral dust can be transported from the Western IGP towards the Himalayas and NCO-P, as recorded during 12-22 June 2006 episode (Bonasoni et al., 2008). A pronounced change in the NCO-P atmospheric composition occurred during the post-monsoon when significant increases in $\mathrm{BC}$, scattering coefficient, $\mathrm{PM}_{1}$ and $\mathrm{O}_{3}$ were observed (Table 2). Such changes became increasingly marked in winter and even more evident in pre-monsoon season (Fig. 7), following the change in weather conditions and atmospheric circulation. In fact, most of the post-monsoon $(56 \%)$ and winter $(77 \%)$ was characterised by a synoptic westerly circulation that favoured the transport of air masses from "WNA", "W-EU" and "W-ME", as indicated by LAGRANTO analyses (Figs. 5 and 6). Nevertheless, the highest sea- sonal values of $\mathrm{BC}\left(316.9 \mathrm{ng} \mathrm{m}^{-3}\right)$, scattering coefficient $\left(11.9 \mathrm{Mm}^{-1}\right), \mathrm{PM}_{1}\left(3.9 \mu \mathrm{g} \mathrm{m}^{-3}\right), \mathrm{O}_{3}(60.9 \mathrm{ppbv})$, coarse particles $\left(0.37 \mathrm{~cm}^{-3}\right)$, were observed during pre-monsoon (Table 2). During this season, influenced mainly by "W-NA" and "REG" air masses, the highest concentrations appear strongly influenced by local/regional atmospheric circulations associated to the valley breeze system, which might favour the direct transport of brown cloud pollutants to the Himalayas, as shown in the following Section.

\subsection{Influence of direct transport of brown cloud on atmospheric composition at NCO-P}

The IGP in south Asia (the northwest to northeast region extending from eastern Pakistan, across India to Bangladesh and Myanmar), is one of the regions identified as a brown cloud hot spot, i.e. a region with anthropogenic $A O D>0.3$ and absorbing AOD $>0.03$ (Ramanathan et al., 2007). In particular, the long, dry season in the south Asian region and the persistent subsidence and trade wind inversion characterising the winter and pre-monsoon seasons, strongly inhibit the ventilation and dispersion of pollutants, favouring their build-up in the lower troposphere (Ramanathan et al., 2008). The typical meteorological conditions also promote an ideal environment for the onset of wildfires and agricultural fires, which represent an important additional source of carbonaceous aerosol and $\mathrm{O}_{3}$ precursors in atmosphere (Novelli et al., 2003; Bond et al., 2004; Badarinath et al., 2009). On the Indian sub-continent, alongside anthropogenic pollution, air-masses rich in mineral aerosol can plausibly affect the lower troposphere reaching the slopes of the southern $\mathrm{Hi}$ malayas in the pre-monsoon period (Liu et al., 2008a; Gautam et al., 2009). Such air masses can frequently reach NCO$\mathrm{P}$ under valley wind breezes, as indicated by the analysis of Vy and SH diurnal behaviours (Sect. 3.3 and Fig. 4) and also traced by WRF model simulations for the Khumbu valley (see supplementary material). For instance, by analysing NCO-P SH behaviour, as already done in other mountain regions by Zellwegger et al. (2003) and Henne at al. (2008), we found that $90 \%$ of pre-monsoon days were characterised by well developed diurnal breeze cycle. In view of the above 


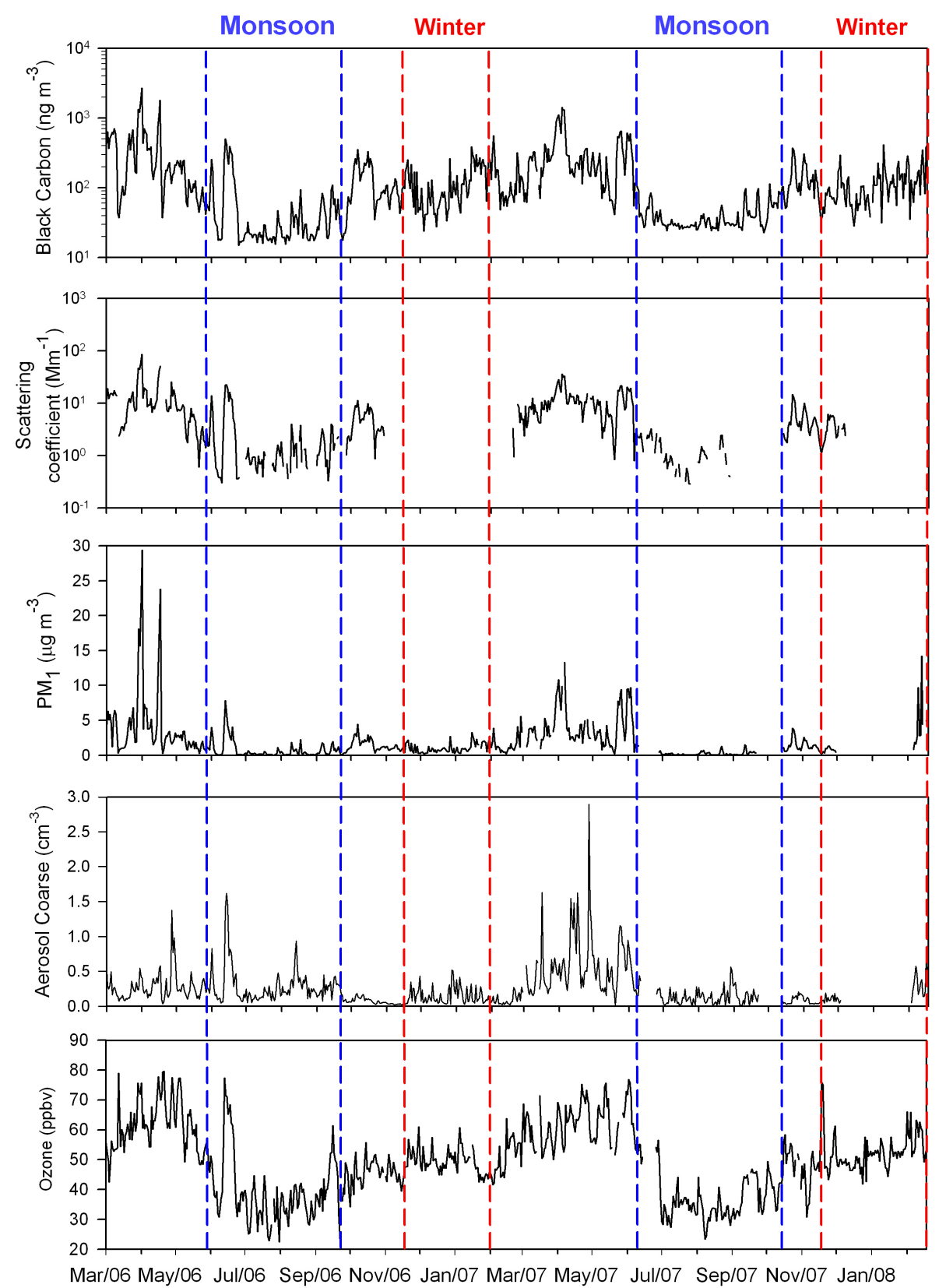

Fig. 7. Seasonal time series (daily averages) of $\mathrm{BC}$, aerosol scattering coefficient, $\mathrm{PM}_{1}$, coarse particle number and surface $\mathrm{O}_{3}$ at $\mathrm{NCO}-\mathrm{P}$ from March 2006 to February 2008. Seasons (as defined in Table 1) are also reported: red - winter; light blue - monsoon. BC is reported by log-scale on y-axis.

considerations and experience gained in other mountain areas (e.g. Carnuth et al., 2002; Henne at al., 2004), this suggests that Khumbu valley represents a "natural chimney" through which brown cloud can be directly vented to the high Himalayas and middle/upper troposphere.

To study the "direct" influence of brown cloud on the atmospheric composition at NCO-P, investigating the possibility that brown cloud pollutants are transported to high altitudes along the Himalayan valley paths, we focused on the behaviour of the principal "Brown Cloud tracers" (i.e. BC, aerosol scattering coefficient, $\mathrm{PM}_{1}$ ) continuously monitored at the NCO-P during periods characterized by the presence of $\mathrm{ABC}$ over the Himalayan foothills and North IGP (box area $26^{\circ} \mathrm{N} \leq$ Lat $\leq 27.5^{\circ} \mathrm{N} ; 83^{\circ} \mathrm{E} \leq$ Lon $\leq 88^{\circ} \mathrm{E}$, see Fig. 8), as deduced by MODIS observations (MOD08_D3.005 product). According to Ramanathan et al. (2007), the presence of this $\mathrm{ABC}$ hot spots has been identified by daily MODIS AOD values at $550 \mathrm{~nm}$ larger than $>0.4$ on the considered 


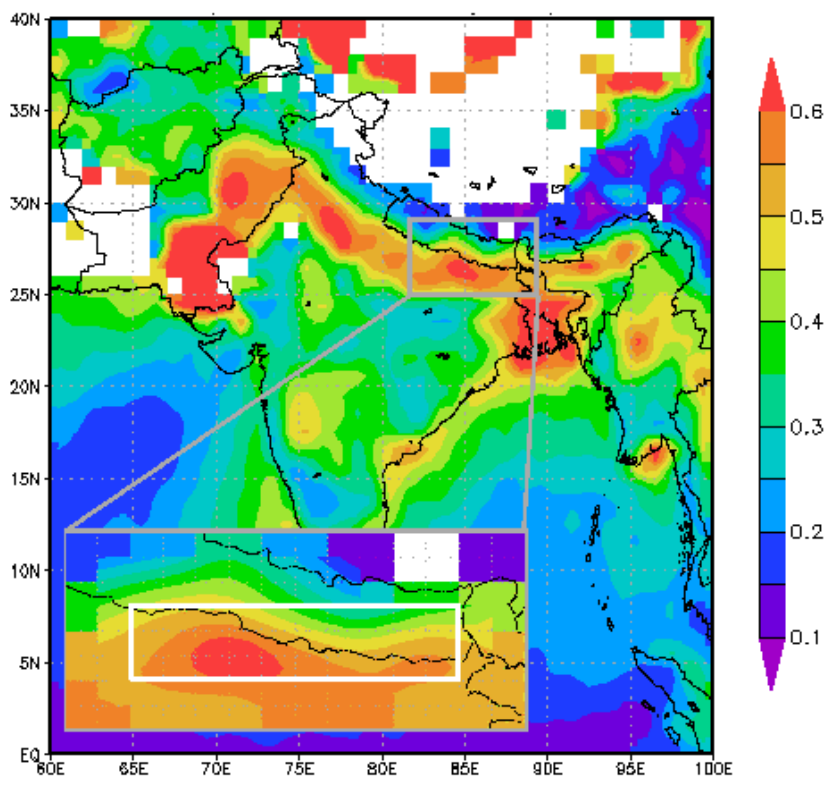

Fig. 8. Satellite (MODIS) integrated AOD over South Asia during pre-monsoon 2006 . The white box in the zoomed region represents the area $\left(26^{\circ} \mathrm{N} \leq\right.$ Lat $\leq 27.5^{\circ} \mathrm{N} ; 83^{\circ} \mathrm{E} \leq$ Lon $\left.\leq 88^{\circ} \mathrm{E}\right)$ used to calculate daily AOD values over the Himalayan foothills and North IGP (courtesy of Giovanni on-line data system from the NASA GES DISC).

box area (Fig. 8). In order to verify whether the high concentration of pollutants measured at NCO-P are due to ABC air masses transported directly by breeze circulation towards the high Himalayas up to the site, periods were selected that were characterised by up-valley wind $\left(\mathrm{Vy}>0 \mathrm{~m} \mathrm{~s}^{-1}\right)$ and by in-situ $\mathrm{BC}$, aerosol scattering coefficient and $\mathrm{PM}_{1}$ values significantly greater than their seasonal background value (i.e. exceeding the $2 \sigma$ confidence level). Such background values were defined based on the analysis of LAGRANTO backtrajectories, i.e. selecting night-time data recorded with airmasses that never descended below the NCO-P altitude during the five-day journey to the measurement site. It should be noted that also total particle number (including ultrafine particles) can be usually related to polluted air-mass transport. However, at the NCO-P this parameter cannot be considered an unambiguous tracer for combustion processes due to frequent new particle formation events (e.g. Venzac et al., 2008; Sellegri et al., 2010). Thus, in this work we preferred to evaluate pollution transport only basing on $\mathrm{PM}_{1}$, $\mathrm{BC}$ and scattering variability. Using this combined methodology, 50 days were identified as being influenced by direct atmospheric brown cloud transport to NCO-P, $87 \%$ of them during pre-monsoon, $9 \%$ during the winter and $4 \%$ in post-monsoon. The 39 days identified during the premonsoon indicated this to be the season most frequently influenced by strong brown cloud transport episodes (20\% of pre-monsoon days). This can be also related to the more ef- ficient vertical mixing of south Asian lower troposphere during the pre-monsoon, when the highest seasonal mixing layer heights are observed over South Asia (e.g. Vernekar et al., 2003) and the highest up-valley wind speed were recorded at NCO-P (see Sect. 3.3). In fact, in comparison with the pre-monsoon seasonal average values, during these hot spots, significantly higher BC (1974.1 $\left.\mathrm{ng} \mathrm{m}^{-3}\right)$, scattering coefficient $\left(57.7 \mathrm{Mm}^{-1}\right), \mathrm{PM}_{1}\left(23.5 \mu \mathrm{g} \mathrm{m}^{-3}\right)$, coarse particles $\left(0.64 \mathrm{~cm}^{-3}\right)$ and $\mathrm{O}_{3}(69.2 \mathrm{ppbv})$ were recorded at $\mathrm{NCO}-$ $\mathrm{P}$ during the afternoon (for $4 \mathrm{~h}$, on average). The increase in these values, ranging from $13.6 \%$ for $\mathrm{O}_{3}$ to $522.9 \%$ for $\mathrm{BC}$, clearly indicates that, thanks to the day-time up-valley breeze, the Khumbu valley represents an efficient and persistent channel for the transport of large amounts of brown cloud pollutants, which during this season pile up from the Indian-Nepalese plains against the Himalayas slopes, as also deduced from satellite data (Fig. 8). The observations made so far confirm that the phenomenon observed at NCO-P is mainly concentrated in the pre-monsoon, which is therefore the season most favourable to the transport of elevated pollutant concentrations up to high-altitudes, where they may contribute to the atmospheric heating and to the melting of snowpacks and glaciers in the Himalayas (Ramanathan and Carmichael, 2008).

\section{Conclusions}

Since March 2006, continuous observations of meteorological variables and atmospheric composition have been carried out at the Nepal Climate Observatory-Pyramid (NCO-P), the highest WMO-GAW Station sited at $5079 \mathrm{ma.s.1.,}$ not far from the Everest Base Camp. These activities are performed in the framework of ABC (Atmospheric Brown Clouds) UNEP and SHARE (Station at High Altitude for Environmental Research) Ev-K2-CNR projects. In the present paper, the first two years (March 2006-February 2008) of observations are introduced and discussed, in relation to seasonal weather conditions and atmospheric circulations, investigating the possible influence of atmospheric brown cloud hot spots on NCO-P atmospheric composition.

Himalayan high-altitude meteorology is strongly influenced by the Asian monsoon circulation and by local mountain wind system, with a strong diurnal valley wind and a weak mountain night-breeze. In the southern Himalayas, the seasonal meteorological conditions are influenced by the development in the upper troposphere of the "Tibetan High" during the summer season and the oscillation of the subtropical jest stream, as well as the passage of eastward propagating synoptic disturbances during winter. This is reflected by the seasonal behaviour of the atmospheric parameters recorded at NCO-P. In fact, the highest seasonal values of temperature $\left(1.7^{\circ} \mathrm{C}\right)$, relative humidity $(94 \%)$ and atmospheric pressure $(552.4 \mathrm{hPa})$ were registered during the monsoon season, also characterized by a low frequency $(10 \%)$ 
of day-time cloud-free skies and the largest amount of rain precipitation (seasonal cumulative value: $237 \mathrm{~mm}$ ). Conversely, the lowest seasonal temperature $\left(-6.3{ }^{\circ} \mathrm{C}\right)$, relative humidity $(22 \%)$ and atmospheric pressure $(546.8 \mathrm{hPa})$ values were recorded during winter, the season being characterised by mainly cloud-free sky conditions and rare thick clouds. The integrated analysis of relative humidity and wind regime changes permitted the definition of the onset dates of the monsoon season, 21 May 2006 and 6 June 2007, showing that in the Southern Himalayas significant changes in mountain weather regime strongly anticipate the precipitation onset, with up-valley winds occurring also during the night.

During the pre-monsoon the highest seasonal values of $\mathrm{BC}$ (316.9 $\left.\mathrm{ng} \mathrm{m}^{-3}\right)$, aerosol scattering coefficient $\left(11.9 \mathrm{Mm}^{-1}\right)$, $\mathrm{PM}_{1}\left(3.9 \mu \mathrm{g} \mathrm{m}^{-3}\right)$, coarse particles $\left(0.37 \mathrm{~cm}^{-3}\right)$ and $\mathrm{O}_{3}$ (60.9 ppbv) were observed, while the lowest concentrations occurred during the monsoon for BC $\left(49.6 \mathrm{ng} \mathrm{m}^{-3}\right)$ scattering $\left(2.2 \mathrm{Mm}^{-1}\right), \mathrm{PM}_{1}\left(0.6 \mathrm{mg} \mathrm{m}^{-3}\right)$ and $\mathrm{O}_{3}(38.9 \mathrm{ppbv})$, and during the post-monsoon for coarse particles $\left(0.07 \mathrm{~cm}^{-3}\right)$, showing a clear seasonal variation of these compounds at NCO-P. Such behaviours can be explained in terms of the different seasonal atmospheric conditions. In fact, as also shown by the analysis of in-situ meteorological parameters and 5-day LAGRANTO back-trajectory cluster analyses, on the synoptic scale, a westerly dry circulation prevails from October to May, while wet air-masses from South Asia are more frequently advected to the NCO-P during the summer monsoon.

The pristine atmospheric conditions of the Himalayas can be influenced by the transport of polluted air masses coming from South Asia and IGP. The emissions from fossil fuel combustion, biomass burning, bio-fuel cooking and heating, favour the formation during the dry season of the atmospheric brown cloud, which extends from the Indian Ocean to the Himalayan ridge. The possibility that the brown cloud is transported towards the Himalayas and vented along the mountain valleys, has been investigated in this study on the basis of AOD values over the IGP, the valley breeze circulation system, and continuous NCO-P observations of BC, aerosol scattering coefficient and $\mathrm{PM}_{1}$.

Occurrences of the brown cloud over the Himalayan foothills and Northern IGP were identified by high AOD values ( $>0.4)$ and associated to the high concentrations of pollutants measured at NCO-P on days characterised by upvalley breeze circulation $\left(\mathrm{Vy}>0 \mathrm{~m} \mathrm{~s}^{-1}\right)$. It was found that the direct transport of brown cloud influencing the atmospheric composition at NCO-P occurred on 50 days, $4 \%$ in the post-monsoon, $9 \%$ during the winter and $87 \%$ during the pre-monsoon, corresponding to $20 \%$ of pre-monsoon days and indicating the latter to be the season most frequently influenced by strong brown cloud transport episodes. During the afternoon pre-monsoon hotspots, a strong increase in BC $(+522 \%), \mathrm{PM}_{1}(+502 \%)$ and scattering coefficient $(+385 \%)$ mean values was registered in respect to seasonal values, and a significant increase in coarse particles $(+38 \%)$ and $\mathrm{O}_{3}$
$(+13 \%)$ concentrations was also found, as reported in $\mathrm{Ta}-$ ble 2 . The high values measured at NCO-P confirmed that when the atmospheric brown cloud extends as far as the Himalayan foothills and the valley breeze is active, the mountain valleys can represent an efficient channel favouring the transport of pollutants to high altitudes.

In the framework of the ABC UNEP project, the results presented here contribute to filling the gap in knowledge on atmospheric composition over the high Himalayas, providing the basis for a better evaluation of the impact of anthropogenic and natural processes on air-quality and radiative forcing in this critical region (Ramanathan et al., 2008). The other papers presented in this special issue (Cristofanelli et al., 2010; Decesari et al., 2010; Gobbi et al., 2010; Marinoni et al., 2010; Marcq et al., 2010; Sellegri et al., 2010 and Duchi et al., 2010) give more specific pictures of the atmospheric composition in the Himalayas, also providing new insights into the basic processes governing its variability. All of the findings, based on two years of continuous atmospheric composition observations, offer clear evidence that, particularly during the pre-monsoon, the southern side of the high Himalayas is impacted by transport of brown cloud pollutants. Therefore, it seems very important that the extension of $\mathrm{ABC}$ project should be matched by suitable policies by local governments and institutions, who must aim to promote an appreciable reduction of pollutants and climate-altering emissions, as already proposed in the context of the SURYA project (Ramanathan et al., 2009) and COP15 in Copenhagen (EPA, 2009).

\section{Supplementary material related to this article is available online at: http://www.atmos-chem-phys.net/10/7515/2010/ acp-10-7515-2010-supplement.pdf.}

Acknowledgements. This work was carried out in the framework of the UNEP-ABC (Atmospheric Brown Clouds) and it was funded by Ev-K2-CNR-SHARE (Stations at High Altitude for Research on the Environment) projects. Contributions from CNRS through the PICS bilateral program between CNR and CNRS and through the LEFE-INSU program are gratefully acknowledged. The authors would like to thank Tenzing Chhottar Sherpa, Kaji Bista, Laxman Adhikary, Pema Sherpa, Lhakpa Tshering Sherpa, Lakpa Tenzi Sherpa, Chhimi Tenzing Sherpa and Hari Shrestha for their support at the Nepal Climate Observatory-Pyramid. The authors are also grateful to EMPA-WCC for providing the travel standard used to intercompare the NCO-P ozone analyser, and to NASA World Wind for the MODIS and OnEarth Landsat 7 image. Analyses and visualizations of MODIS-AOD used in this paper were produced with the Giovanni online data system, developed and maintained by the NASA GES DISC. We also acknowledge the MODIS mission scientists and associated NASA personnel for the production of the data used in this research effort.

Edited by: J. J. Schauer 


\section{References}

Badarinath, K. V. S., Kharol, S. K., and Sharma, A. R.: Long-range transport of aerosols from agriculture crop residue burning in Indo-Gangetic Plains: A study using LIDAR, ground measurements and satellite data, J. Atmos. Sol.-Terr. Phys., 71, 112-120, 2009.

Barnard, J. C. and Long, C. N.: A simple empirical equation to calculate cloud optical thickness using shortwave broadband measurements, J. Appl. Meteorol., 43, 1057-1066, 2004.

Barros, A. P. and Lang, T. J.: Monitoring the Monsoon in the Himalayas: Observations in Central Nepal, June 2001, Mon. Weather Rev., 131, 1408-1427, 2003.

Baudo, R., Schommer, B., Belotti, C., and Vuillermoz, E.: From Himalaya to Karakoram: the spreading of the project Ev-K2$\mathrm{CNR}$, in: Mountains witnesses of global changes research in the Himalaya and Karakoram; SHARE- Asia project, Developments in Earth Surface Processes, edited by: Baudo, R., Tartari, G., and Vuillermoz, E., Elsevier, Amsterdam, 10, 33-49. 2007.

Bertolani, L., Bollasina, M., and Tartari, G.: Recent biennial variability of meteorological features in the Eastern Highland Himalayas, Geophys. Res. Lett., 27, 2185-2188, 2000.

Böhmer, J.: General climatic controls and topoclimatic variations in Central and High Asia, BOREAS, 35, 279-294, 2006.

Bollasina, M., Bertolani, L., Tartari, G.: Meteorological observations at high altitude in Khumbu Valley, Nepal Himalayas, 19941999, Bull. Glaciol. Res., 19, 1-11, 2002.

Bonasoni, P., Laj, P., Bonafè, U., Calzolari, F., Cristofanelli, P., Marinoni, A., Roccato, F., Facchini, M. C., Fuzzi, S., Gobbi, G. P., Pichon, J. M., Venzac, H., Sellegri, K., Villani, P., Maione, M., Arduini, J., Petzold, A., Sprenger, M., Verza, G. P., and Vuillermoz, E.: The ABC-Pyramid: a scientific laboratory at $5079 \mathrm{~m}$ a.s.l. for the study of atmospheric composition change and climate. in: Mountains witnesses of global changes research in the Himalaya and Karakoram; SHARE- Asia project, Developments in Earth Surface Processes, edited by: Baudo, R., Tartari, G., and Vuillermoz, E., Elsevier, Amsterdam, 67-73, 65, Chapter 10, 2007.

Bonasoni, P., Laj, P., Angelini, F., Arduini, J., Bonafè, U., Calzolari, F., Cristofanelli, P., Decesari, S., Facchini, M. C., Fuzzi, S., Gobbi, G. P., Maione, M., Marinoni, A., Petzold, A., Roccato, F., Reger, J. C., Sellegri, K., Sprenger, M., Venzac, H., Verza, G.P., Villani, P., and Vuillermoz, E.: The ABC-Pyramid Atmospheric Research Observatory in Himalayas for aerosol, ozone and halocarbon measurements, Sci. Total Environ., 391, 241-251, 2008.

Bond, T. C., Streets, D. G., Yarber, K. F., Nelson, S. M., Woo, J.H., and Klimont, Z.: A technology based global inventory of black carbon and organic carbon emissions from combustion, J. Geophys. Res., 109, D14203, doi:10.1029/2003JD003697, 2004.

Carnuth, W., Kempfer, U., and Trickl, T.: Highlights of the Tropospheric Lidar Studies at IFU within the TOR Project, Tellus B, 54, 163-185, 2002.

Carrico, C. M., Bergin, M. H., Shrestha, A., Dibb, J. E., Gomes, L., and Harris, J.M.: The importance of carbon and mineral dust to seasonal aerosol properties in the Nepal Himalayas, Atmos. Environ., 37, 2811-2824, 2003.

Chapman, S. and Lindzen, R. S.: Atmospheric Tides. D. Reidel, 200 pp., 1970.

Cristofanelli, P., Marinoni, A., Arduini, J., Bonafè, U., Calzolari, F., Colombo, T., Decesari, S., Duchi, R., Facchini, M. C., Fierli,
F., Finessi, E., Maione, M., Chiari, M., Calzolai, G., Messina, P., Orlandi, E., Roccato, F., and Bonasoni, P.: Significant variations of trace gas composition and aerosol properties at $\mathrm{Mt}$. Cimone during air mass transport from North Africa contributions from wildfire emissions and mineral dust, Atmos. Chem. Phys., 9, 4603-4619, doi:10.5194/acp-9-4603-2009, 2009.

Cristofanelli, P., Bracci, A., Sprenger, M., Marinoni, A., Bonafè, U., Calzolari, F., Duchi, R., Laj, P., Pichon, J. M., Roccato, F., Venzac, H., Vuillermoz, E., and Bonasoni, P.: Tropospheric ozone variations at the Nepal climate observatory pyramid (Himalayas, $5079 \mathrm{~m}$ a.s.1.) and influence of stratospheric intrusion events, Atmos. Chem. Phys. Discuss., 10, 1483-1516, doi:10.5194/acpd10-1483-2010, 2010.

Decesari, S., Facchini, M. C., Carbone, C., Giulianelli, L., Rinaldi, M., Finessi, E., Fuzzi, S., Marinoni, A., Cristofanelli, P., Duchi, R., Bonasoni, P., Vuillermoz, E., Cozic, J., Jaffrezo, J. L., and Laj, P.: Chemical composition of $\mathrm{PM}_{10}$ and $\mathrm{PM}_{1}$ at the highaltitude Himalayan station Nepal Climate Observatory-Pyramid (NCO-P) (5079 m a.s.1.), Atmos. Chem. Phys., 10, 4583-4596, doi:10.5194/acp-10-4583-2010, 2010.

Dorling, S. R., Davies, T. D., and Pierce, C. E.: Cluster-Analysis - a Technique for Estimating the Synoptic Meteorological Controls on Air and Precipitation Chemistry - Method and Applications, Atmos. Environ., Part a-General Topics, 26, 2575-2581, 1992.

Duchi, R., Cristofanelli, P., Marinoni, A., Laj, P., Marcq, S., Villani, P., Sellegri, K., Angelini, F., Calzolari, F., Decesari, S., Gobbi, GP., Verza, GP., Vuillermoz, E., and Bonasoni, P.: Continuous observations of dust synoptic-scale transport at the Nepal Climate Observatory-Pyramid (5079 m a.s.1.) in the Himalayas, in preparation, Atmos. Chem. Phys. Discuss., 2010.

EPA, Partnership for Clean Indoor Air Side Event. COP15, Copenhagen, 9th December, 2009.

Gautam, R., Liu, Z., Singh, R. P., and Hsu, N. C.: Two contrasting dust-dominant periods over India observed from MODIS and CALIPSO, Geophys. Res. Lett., 36, L06813, doi:10.1029/2008GL036967, 2009.

GAW report of the WMO meeting of experts on the quality assurance plan for the Global Atmospheric Watch (GAW), GarmischPartenkirchen, Germany, 26-30 March, 1992.

Gobbi, G. P., Angelini, F., Bonasoni, P., Verza, G. P., Marinoni, A., and Barnaba, F.: Sunphotometry of the 2006-2007 aerosol optical/radiative properties at the Himalayan Nepal Climate Observatory - Pyramid (5079 m a.s.1.), Atmos. Chem. Phys. Discuss., 10, 1193-1220, doi:10.5194/acpd-10-1193-2010, 2010.

Henne, S., Furger, M., Nyeki, S., Steinbacher, M., Neininger, B., de Wekker, S. F. J., Dommen, J., Spichtinger, N., Stohl, A., and Prévôt, A. S. H.: Quantification of topographic venting of boundary layer air to the free troposphere, Atmos. Chem. Phys., 4, 497509, doi:10.5194/acp-4-497-2004, 2004.

Henne, S., Dommen, J., Neininger, B., Reimann, S., Staehelin, J., and Prévôt, A. S. H.: Influence of mountain venting in the Alps on the ozone chemistry of the lower free troposphere and the European pollution export, J. Geophys. Res., 110, D22307, doi:10.1029/2005JD005936, 2005.

Henne, S., Klausen, J., Junkermann, W., Kariuki, J. M., Aseyo, J. O., and Buchmann, B.: Representativeness and climatology of carbon monoxide and ozone at the global GAW station Mt. Kenya in equatorial Africa, Atmos. Chem. Phys., 8, 3119-3139, doi:10.5194/acp-8-3119-2008, 2008. 
Hindman, E. E. and Upadhyay, B. P.: Air pollution transport in the Himalayas of Nepal and Tibet during the 1995-1996 dry season, Atmos. Environ., 36, 727-739, doi:10.1016/S13522310(01)00495-2, 2002.

Krishnamurti, T. N. and Blame, H. N.: Oscillations of a monsoon system, Part. 1 Observational aspects, J. Atmos. Sci., 33, 19371954, 1976.

Liu, D., Wang, Z., Liu, Z., Winker, D., and Trepte, C.: A height resolved global view of dust aerosols from the first year CALIPSO lidar measurements, J. Geophys. Res., 113, D16214, doi:10.1029/2007JD009776, 2008.

Long C. N. and Ackerman, T. P.: Identification of clear skies from broadband pyranometer measurements and calculation of downwelling, shortwave cloud effects, J. Geophys. Res., 105(D12), 15609-15626, 2000.

Marcq, S., Laj, P., Villani, P., Roger, J. C., Sellegri, K., Bonasoni, P., Marinoni, A., Cristofanelli, P., Vuillermoz, E., Verza, G. P., and Bergin, M.: Aerosol Optical Properties and Radiative Forcing in the High Himalayas Based on Measurements at the Nepal Climate Observatory-Pyramid Site (5079 m a.s.1), Atmos. Chem. Phys., 10, 5859-5872, doi:10.5194/acp-10-5859-2010, 2010.

Marinoni, A., Cristofanelli, P., Laj, P., Duchi, R., Calzolari, F., Decesari, S., Sellegri, K., Vuillermoz, E., Verza, G. P., Villani, P., and Bonasoni, P.: Aerosol mass and black carbon concentrations, two year-round observations at NCO-P (5079 m, Southern Himalayas), Atmos. Chem. Phys. Discuss., 10, 8379-8413, doi:10.5194/acpd-10-8379-2010, 2010.

Novelli, P. C., Masarie, K. A., Lang, P. M., Hall, B. D., Myers, R. C., and Elkins, J. W.: Reanalysis of tropospheric CO trends: Effects of the 1997-1998 wildfires, J. Geophys. Res., 108(D15), 4464, doi:10.1029/2002JD003031, 2003.

Panday, A. K. and Prinn, R. G.: Diurnal cycle of air pollution in the Kathmandu Valley, Nepal: Observations, J. Geophys. Res., 114, D09305, doi:10.1029/2008JD009777, 2009.

Petenko, I. V. and Argentini, S.: The annual behaviour of the semidiurnal and diurnal pressure variations in East Antarctica, J. Appl. Met., 41(11), 1093-1100, 2002.

Petzold, A., Kramer, H., and Schonlinner, M.: Continuous measurement of atmospheric black carbon using a multi-angle absorption photometer, Environ. Sci. Pollut. R., 4, 78-82, 2002.

Phandis, M. J., Levy, H. II, and Moxim, W. J.: On the evolution of pollution from South and Southeast Asia during the winter spring monsoon, J. Geophys. Res., 107(D24), 4790, doi:10.1029/2002JD002190, 2002.

Pudasainee, D., Sapkota, B., Shrestha, M. L., Kaga, A., Kondo, A., and Inoue, Y.: Ground level ozone concentrations and its association with NOx and meteorological parameters in Kathmandu valley, Nepal, Atmos. Environ., 40(40), 8081-8087, 2006.

Ramanathan, V. and Crutzen, P. J.: New Directions: Atmospheric Brown "Clouds", Atmos. Environ. 37, 4033-4035, 2003.

Ramanathan, V., Li, F., Ramana, M. V., Praveen, P. S., Kim, D., Corrigan, C. E., Nguyen, H., Stone, E. A., Schauer, J. J., Carmichael, G. R., Adhikary, B., Yoon, S. C.: Atmospheric brown clouds: Hemispherical and regional variations in longrange transport, absorption, and radiative forcing, J. Geophys. Res., 112, D22S21, doi:10.1029/2006JD008124, 2007.

Ramanathan, V., Agrawal, M., Akimoto, H., Auffhammer, M., Devotta, S., Emberson, L., Hasnain, S. I., Iyngararasan, M., Jayaraman, A., Lawrence, M., Nakajima, T., Oki, T., Rodhe, H.,
Ruchirawat, M., Tan, S. K., Vincent, J., Wang, J. Y., Yang, D., Zhang, Y. H., Autrup, H., Barregard, L., Bonasoni, P., Brauer, M., Brunekreef, B., Carmichael, G., Chung, C. E., Dahe, J., Feng, Y., Fuzzi, S., Gordon, T., Gosain, A. K., Htun, N., Kim, J., Mourato, S., Naeher, L., Navasumrit, P., Ostro, B., Panwar, T., Rahman, M. R., Ramana, M. V., Rupakheti, M., Settachan, D., Singh, A. K., Helen, G. St., Tan, P. V., Viet, P. H., Yinlong, J., Yoon, S. C., Chang, W. C., Wang, X., Zelikoff, J., and Zhu, A.: Atmospheric Brown Clouds: Regional Assessment Report with Focus on Asia, Published by the United Nations Environment Programme, Nairobi, Kenya, 2008.

Ramanathan, V. and Carmichael, G.: Global and regional climate changes due to black carbon, Nature Geoscience 1, 221-227, doi:10.1038/ngeo156, 2008.

Saha, A., Pant, P., Dumka, U. C., Hegde, P., Srivastava, M. K., and Sagar, R.: Aerosol Characteristics at a high-altitude station Nainital during the ISRO-GBP Land Campaign-II, in: Proceedings of the SRO-GBP Land-Campaign-II meeting, Physical Research Laboratory, Ahmadabad, 1-2nd March 2005, 2005.

Scheele, M. P. and Siegmund, P. C.: Estimating errors in trajectory forecasts using ensemble predictions, J. Appl. Meteorol., 40, 1223-1232, 2001.

Schiemann, R., Lüthi, D., and Schär, C.: Seasonality and Interannual Variability of the Westerly Jet in the Tibetan Plateau Region, J. Climate, 22, 2940-2957, 2009.

Sellegri, K., Laj, P., Venzac, H., Boulon, J., Picard, D., Villani, P., Bonasoni, P., Marinoni, A., Cristofanelli, P., and Vuillermoz, E.: Seasonal variations of aerosol size distributions based on long-term measurements at the high altitude Himalayan site of Nepal Climate Observatory-Pyramid (5079 m), Nepal, Atmos. Chem. Phys. Discuss., 10, 6537-6566, doi:10.5194/acpd10-6537-2010, 2010.

Shrestha, R. M. and Malla, S.: Air pollution from energy use in a developing country city: The case study of Kathmandu valley, Nepal, Energy, 21, 785-794, 1996.

Tarasova, O. A., Brenninkmeijer, C. A. M., Jöckel, P., Zvyagintsev, A. M., and Kuznetsov, G. I.: A climatology of surface ozone in the extra tropics: cluster analysis of observations and model results, Atmos. Chem. Phys., 7, 6099-6117, doi:10.5194/acp-76099-2007, 2007.

Ueno, K., Kayastha, R. B., Chitrakar, M. R., Bajracharya, O. R., Pokhrel, A. P., Fujinami, H., Kadota, T., Iida, H., Manandhar, D. P., Hattori, M., Yasunari, T., Nakawo, M.: Meteorological observations during 1994-2000 at the Automatic Weather Station (GEN-AWS) in Khumbu region, Nepal Himalayas, Bulletin of Glacier Research., 18, 23-30, 2001.

Ueno, K. and Pokhrel, A. P.: Intra-seasonal variation of surface air temperature in Nepal Himalayas, Mausam, 53, 281-288, 2002.

Ueno, K., Toyotsu, K., Bertolani, L., and Tartari, G.: Stepwise onset of Monsoon Weather Observed in the Nepal Himalayas, Mon. Weather Rev., 136(7), 2507-2522, 2008.

Vernekar, K. G., Sinha, S., Sadani, L. K., Sivaramakrishnan, S., Parasnis, S. S., Brij mohan, Saxena, S., Dharmaraj, Patil, T., M. N., Pillai, J. S., Murthy, B. S., Debaje, S. B. and Bagavathsingh, A.: An overview of the land surface processes experiment (laspex) over a semi-arid region of India, Bound. Lay. Met., 106, 561-572, 2003 
Webster, P. J., Magaa, V. O., Palmer, T. M., Shukla, J., Tomas, R. A., Yanai, M., and Yasunari, T.: Monsoons: processes, predictability, and the prospect of prediction, J. Geophys. Res., 103, $14451-$ $14510,1998$.
Wernli, H. and Davies, H.: A Lagrangian-based analysis of extratropical cyclones. Part I: The method and some applications, Quart. J. Roy. Meteor. Soc., 123, 467-489, 1997. 